\title{
Depicting barbarism on fire: architectural destruction on the Columns of Trajan and Marcus Aurelius Elizabeth Wolfram Thill
}

This article explores the depictions of architecture on the Columns of Trajan and Marcus Aurelius. Trajan's Column alone features depictions of over 300 architectural structures, the vast majority of which can be clearly associated with either Roman or Dacian culture, and which project a clear disparity between those cultures. ${ }^{1}$ On both columns, destruction plays a crucial rôle in the contrast between Roman and indigenous architecture and cultures. On Trajan's, fully one-fourth of Dacian architectural structures are either on fire or threatened by fire. Both Roman soldiers and Dacian warriors participate in this destruction, filling 7 separate sequences that illustrate the annihilation and erasure of Dacian culture in the face of the Roman advance. The theme of architectural destruction as a metaphor for cultural erasure is echoed on the Column of Marcus Aurelius, but with important modifications that speak to differences in how the two monuments portray war, victory, and aggressive imperialism. ${ }^{2}$

I begin with a brief review of previous scholarship on the architectural depictions of both columns. The second part establishes the symbolic importance of depictions of architectural destruction on Trajan's Column. The third section explores the use of architectural destruction on the Column of Marcus Aurelius and compares it to that on Trajan's. The differences in architectural destruction between the two columns are outlined and related to the monuments' broader themes.

\section{Architectural depictions on the columns: previous scholarship and a new approach}

Despite a vast general bibliography for both monuments, ${ }^{3}$ the architectural depictions of Trajan's Column and its successor, the Column of Marcus Aurelius, have been largely

1 I use "culture" here in a broad sense that incorporates: (a) the customary practices, activities and beliefs that can be associated with a particular society; and (b) the material consequences and symbols generated by participation in those practices, activities, and beliefs.

2 For Trajan's Column I follow the traditional scene divisions and numbering system established by Cichorius (1896-1900). For the Column of Marcus Aurelius, I follow the scene divisions and numbering system of Petersen, Domaszewski and Calderini 1896, as cited in Coarelli 2008.

3 For a summary and discussion of the debate over the patronage and artistic forces behind Trajan's Column, see Galinier 2007, 8-30; also, e.g., Coulston 1988, passim; id. 1990b, 300 and 302-3; Lepper and Frere 1988, passim; Settis 1988, 100-2; Coarelli 2000, 30-31; Hölscher 2002, 127-28; Claridge 2007a, 467; Packer 2008, 471-72. For specific discussion of the artistic forces behind the architectural depictions, see Rockwell 1985, 101-5; cf. Coulston 1988, 57. For discussion of the setting of Trajan's Column and its possible relationship to the Temple of Divine Trajan, see, e.g., Packer 1997, 2003 and 2008; Lancaster 1999; Meneghini 2001, 2007 and 2009; La Rocca 2004; Gros 2005; Claridge 2007b; Galinier 2007.

For an examination of the patronage and artistic forces behind the Column of Marcus Aurelius, see, e.g., Coulston 1988, 387-88; Jordan-Ruwe 1990, 67-69; Pirson 1996, 140-41; Beckmann 2003; id. 2005, especially 308-12; id. 2006; id. 2011, 68-127; Clarke 2003, 45-46; Claridge 2005. For discussion of the setting of the Column of Marcus Aurelius, see, e.g., Coulston 1988, 18 and 390; Hanoune 2000, 207; Beckmann 2003, 1-2 and 23; id. 2011, 37-54; Clarke 2003, 45-47; Coarelli 2008, 12-32. For the problem of the date of the Column of Marcus Aurelius, see Jordan-Ruwe 1990, 67-69; Wolff 1990; Hölscher 2000, 94; Beckmann 2003, passim; id. 2011, 19-36; Coarelli 2008, 32-36; Kovács 2009, 159-68 and 181-275. 
neglected. The last decades have seen a significant shift in scholarly approach to both friezes, from viewing them as accurate historical narratives to emphasizing the political, thematic and artistic considerations that affected their design and composition, ${ }^{4}$ but scholarship on the architectural depictions has not seen a corresponding shift in approach.

Comprehensive surveys of the friezes have tended to limit discussion of the architectural depictions to brief descriptions of the illustrated structures; typically, the main interest is the reconstruction of actual physical architecture supposedly depicted on the columns. ${ }^{5}$ The few focussed explorations of the architectural depictions on Trajan's Column are concerned mostly with reconstructing the topography of the Dacian Wars ${ }^{6}$ or specific aspects of ancient architectural practice. ${ }^{7}$ The only recent article on the architecture of the Column of Marcus Aurelius is R. Hanoune's ${ }^{8}$ but it is primarily descriptive. In all of these studies, there has been little attempt to situate the architectural depictions within the thematic context of the columns. An exception is I. Ferris, who briefly addresses the symbolic importance of the architecture on the Column of Marcus Aurelius in delineating Roman from barbarian and in creating a picture of barbarian culture as ephemeral and inferior. ${ }^{9}$

Rather than seeing the architectural depictions as incidental background filler or attempts at documenting actual architectural practice, I consider them to be thematically significant, an active force in the columns' intended messages. In contrast to discussions that treat only individual scenes or depictions, I started with a comprehensive analysis of all the architectural depictions on the two columns, the aim of which was to explore

For Trajan's Column, see, e.g., Settis 1988 and 2005; Coulston 1990b; Baumer, Hölscher and Winkler 1991; Hölscher 1999 and 2002; Elsner 2000; Dillon 2006a. Lehmann-Hartleben 1926 represents an early example of thematic approaches to Trajan's Column. For the Column of Marcus Aurelius, see the articles in Huet and Scheid 2000, especially Elsner and Hölscher; also Pirson 1996; Dillon 2006a; Beckmann 2011. For the relationship between trends in scholarship for the two columns, see Beckmann 2003, 4 and 8.

5 For Trajan's Column, see Lehmann-Hartleben 1926; Lepper and Frere 1988; Koeppel 1991 and 1992; Coarelli 2000; Stefan 2005; Depeyrot 2007. For the Column of Marcus Aurelius, see Caprino et al. 1955; Coarelli 2008.

6 See, e.g., Davies 1920; Rossi 1971.

7 See, e.g., Rossi 1968 and 1971; Hanson 1982, especially 172, 177 and 180-82; Hobley 1982, especially 229, 234, 238, 257, 263 and 269-70, with figs. 12.3-12.5 and pl. 12.10; Richmond 1982. Antonescu 2009 (published posthumously) advocates a comprehensive approach covering all the architectural depictions on the frieze, but his main concern is to reconstruct actual indigenous Dacian architecture based on the depictions. Turcan-Déléani's 1956 article on the column's civilian architecture addresses how compositional issues might affect the potential historicity of the frieze's architectural landscapes. Coulston's (1988, 3 and 136-62; 1990a) evaluation of the military architecture focuses on the classification and structural analysis of the various fortifications, but he also addresses questions of inspiration and execution for the depictions.

8 Hanoune 2000. Architectural depictions are mentioned briefly within the context of a broader discussion of the column as a whole: Pirson 1996, 140, 142-43, 149, 166-67 and 173; Beckmann 2003, 57-58; id. 2011, passim; Coarelli 2008, passim. The early 20th c. brought several short articles debating the structural and anthropological realism of the huts on the Column of Marcus Aurelius, with some discussion of the possible artistic sources: Mielke 1915; Drexel 1918; Behn 1919a and 1919b; see also Hanoune 2000, 208-9. 
and identify quantitative and qualitative trends for the architectural depictions, and to relate those depictions to the monuments' thematic concerns. I will consider one particular aspect of architectural depictions in more detail: the depiction of the destruction of indigenous architecture.

Problems of visibility are obviously a critical concern for such an analysis. ${ }^{10}$ While a full discussion of this issue is beyond the scope of the present article, a few points can be made concerning the visibility of the architectural depictions. Two questions are crucial: (a) Are architectural depictions present and observable in the lower spirals? (b) Could the architectural depictions and their details in the higher, 'invisible' spirals also be relevant for the columns' messages?

Architecture is indeed the first element to appear along both columns' friezes. From a literal perspective it would be the "most visible" element of the friezes. T. Hölscher and $S$. Settis have argued that the lower spirals acted as a kind of summary of the rest of the frieze, conveying the narrative's basic plot and most essential themes. ${ }^{11}$ If so, then the significant amount of space dedicated to architecture in the lower spirals would imply that architecture was one of the most important themes. ${ }^{12}$ On both columns, a contrast between Roman and barbarian architecture, as well as the destruction of the latter, occur well within these 'summarizing' lower spirals and would have been clearly visible.

The second question is more difficult to answer. As for all other elements of the friezes, the level of detail employed in the architectural depictions remains basically the same for the length of the frieze, despite the decreasing visibility of the details. ${ }^{13}$ The visibility of the architectural depictions should thus be considered in the same vein as all other elements of the upper spirals. In this analysis (as in much previous scholarship) the details of the architectural depictions are presumed to be purposeful and are treated as having the potential to play a rôle in the columns' intended effect and messages.

10 For extensive discussion of the problems (both logistical and conceptual) for the visibility of Trajan's frieze, see Galinier 2007, 134-63; also Coulston 1988, 13-14, 18, 30-33, 51 and 107-11; id. 1990b, 296, 299, 301 and 303-4; Settis 1988, 87 and 202-6; id. 2005, 65 and 68-70; Hölscher 1991a, 262-63; id. 2000, 90-91; id. 2002, 139-40; Claridge 1993, 22; Packer 1997, 113; Coarelli 2000, 19-21; Clarke 2003, 35; Dillon 2006a, 259. For discussion of the problem of visibility for the frieze on the Column of Marcus Aurelius, see Coulston 1988, 383-84, 387-88 and 390; Pirson 1996, 171; Hanoune 2000, 206-7; Hölscher 2000, 90-91; Beckmann 2003, 29-30 and 194-202; id. 2011, 187-93; Clarke 2003, 43-45; Brilliant 2007, 485; Coarelli 2008, 46; Kovács 2009, 156.

11 Settis 1988, 109-10; id. 2005, 74-75; Hölscher 1991a, 263-64; id. 2000, 90-91; id. 2002, 139-40.

12 The first spiral of the Column of Marcus Aurelius is derived directly from the first spiral of Trajan's Column, but the architecture is adapted (see p. 303 below).

13 Several scholars have argued that the columns' consistently detailed rendering, rising above the viewer, would encourage the belief that the same high level of documentary accuracy apparently present in the lower spirals would continue for the length of the friezes: Hölscher 1991a, 263-64; id. 2002, 140; Zanker 2000a, vii; Settis 2005, 73. S. Dillon (2006a, 259) has suggested that the columns' endless wealth of detail encourages the viewer to take the reliefs as "objective (and inevitable) historical truth". Thus there has been general consensus that a uniform impression of meticulous and documentary detail for the length of the column was desirable. The easiest way to achieve the impression of a uniform frieze would be actually to produce a uniform frieze. The consistent application of detail, in other words, may have been the product of following the path of least resistance. 


\section{Architectural destruction on Trajan's Column}

The frieze features 326 architectural structures, ${ }^{14}$ the majority of which can be directly associated with either Roman or Dacian cultural influence, and thus classified as "Roman" or "Dacian". A structure has been classified as associated with Rome, or "Roman", if it was: (a) an architectural type with strong links to Rome (e.g., a monumental arch);

(b) part of an urban landscape incorporating such architectural types; or

(c) associated with the Roman army (e.g., camps occupied by legionaries).

A structure was classified as associated with Dacian culture, or "Dacian", if it was:

(a) an unfamiliar, clearly non-Roman, architectural type (e.g., a building on stilts);

(b) part of an urban landscape incorporating such architectural types; or

(c) associated with the Dacian populace through narrative (e.g., structures under explicit Dacian occupation). ${ }^{15}$

For Roman architectural structures, $70 \%$ are specifically depicted as stone-built, while only $16 \%$ are depicted as made of wood. ${ }^{16}$ For Dacian structures, $25 \%$ are depicted as stone and $55 \%$ as wooden. This distinction in primary construction materials between Roman and Dacian architecture draws a contrast between the architecture (and, by extension, the cultures) of the two peoples. Roman architecture is portrayed as permanent and

All numbers, percentages, typologies, and classifications for Trajan's Column are derived from a comprehensive catalogue of architectural depictions compiled during the research for my thesis (Wolfram 2007) and published in abbreviated form on the AJA Web site (http://www. ajaonline.org) under "Supplemental Data" in association with Wolfram Thill 2010. In compiling this catalogue I relied on Coarelli's 2000 edition of photographs of the frieze, in combination with my own photographs of the casts in the Museo della Civiltà Romana (here figs. 1, 3, 5-11 and $15 \mathrm{~b}-\mathrm{c})$. I thank the museum for permission to publish them. Wolfram Thill 2010, 35-36.

16 I classified a structure as "stone" if it presented some combination of rectangular hatching, arches, or other structural features possible only in stone or concrete. I classified a structure as "wooden" if it had planking and/or pegs clearly shown; see Wolfram Thill 2010, 28-29. These percentages include 46 Roman military camps classified as "stone". There has been considerable debate as to what construction method is depicted for the camps on Trajan's Column, with most scholars (e.g., Hobley 1982, especially 269-70; Richmond 1982; Johnson 1983; Lepper and Frere 1988; Coulston 1990a) arguing that primarily turf-and-timber construction is depicted. By contrast, I have argued (2010, 27 and 29-35) for an intentional, ideologically-significant depiction of all Roman military fortifications as made of stone, for the following summarized reasons:

(a) although the depictions of camps preserve some elements, such as timber gateways or tents, that coincide well with the architectural reality of the frontier, these elements are not applied absolutely consistently, accurately, or precisely;

(b) apparent elements of timber architecture, such as wooden catwalks (shown as roundels), often appear alongside apparent elements of stone architecture, such as merlons, with no reason to privilege the former over the latter;

(c) the hatching used on military fortifications had been used for centuries, as well as elsewhere on the column, to depict stone architecture (e.g., in the Esquiline frieze, the Basilica Aemilia frieze, the so-called Villa Medici reliefs, Trajan's Column Scene III), and stone would be the hatching's default interpretation without further clarification.

Even if all camps are discounted, then $48 \%$ (108) of all Roman structures still would be classified as stone, a considerably higher percentage than for Dacian architecture. If only camps specifically marked with roundels/timber walkways (16) are discounted, then $61 \%$ (138) of Roman structures would be classified as stone. 


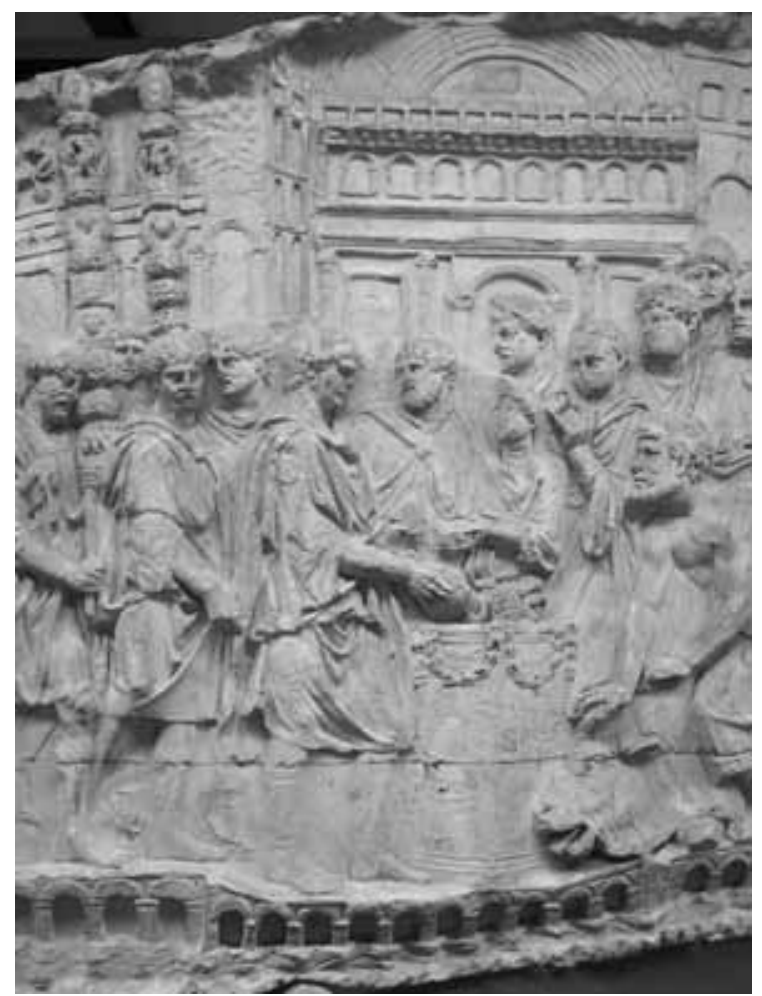

Fig. 1. Trajan's Column, sophisticated stone architecture in peaceful towns. Left: Trajan sacrificing with local population (Scene LXXXVI). Right: Supplying the Roman army (Scene XXXIII).

shown either on fire or threatened by fire. ${ }^{19}$ This destruction takes place over 7 separate sequences, from Scene XXV to the final full scene (fig. 2).

The column's 7 destruction sequences show immense variety. ${ }^{20}$ Trajan's own relationship to the destruction changes as one detects a general increase in the physical and conceptual distance between the emperor and the destruction. The agents of the destruction include Roman legionaries, auxiliaries, ${ }^{21}$ and eventually the Dacians themselves.

17 For a similar phenomenon on the Column of Marcus Aurelius, see Ferris 2009, 157.

18 E.g., Scenes XXXIII and LXXXVI; Wolfram Thill 2010, 36. Many such architectural backdrops are paired with scenes of sacrifice. For the importance of sacrifice scenes on the column as a display of loyalty to the empire, see Winkler 1991.

19 Wolfram Thill 2010, 38.

20 On the importance of variety for the composition and messages of Trajan's Column, see Hölscher 1991b.

21 For differentiation on Trajan's Column between legionaries and auxiliaries based on costume, standards and activity, see Coulston 1988, 40-43 and passim. Beckmann (2003, 96 and 179-81) has questioned the identification of legionaries versus auxiliaries on Trajan's Column based solely on costume but he concludes (184) that soldiers wearing segmented armor were meant in some way to reflect legionaries' duties, including construction, for both columns. The fact that all but three soldiers engaged in construction on Trajan's Column are shown wearing segmented armor (Coulston 1988, 68) suggests that some distinction in types of soldier based on 
SE

NE

NW

SW

SE

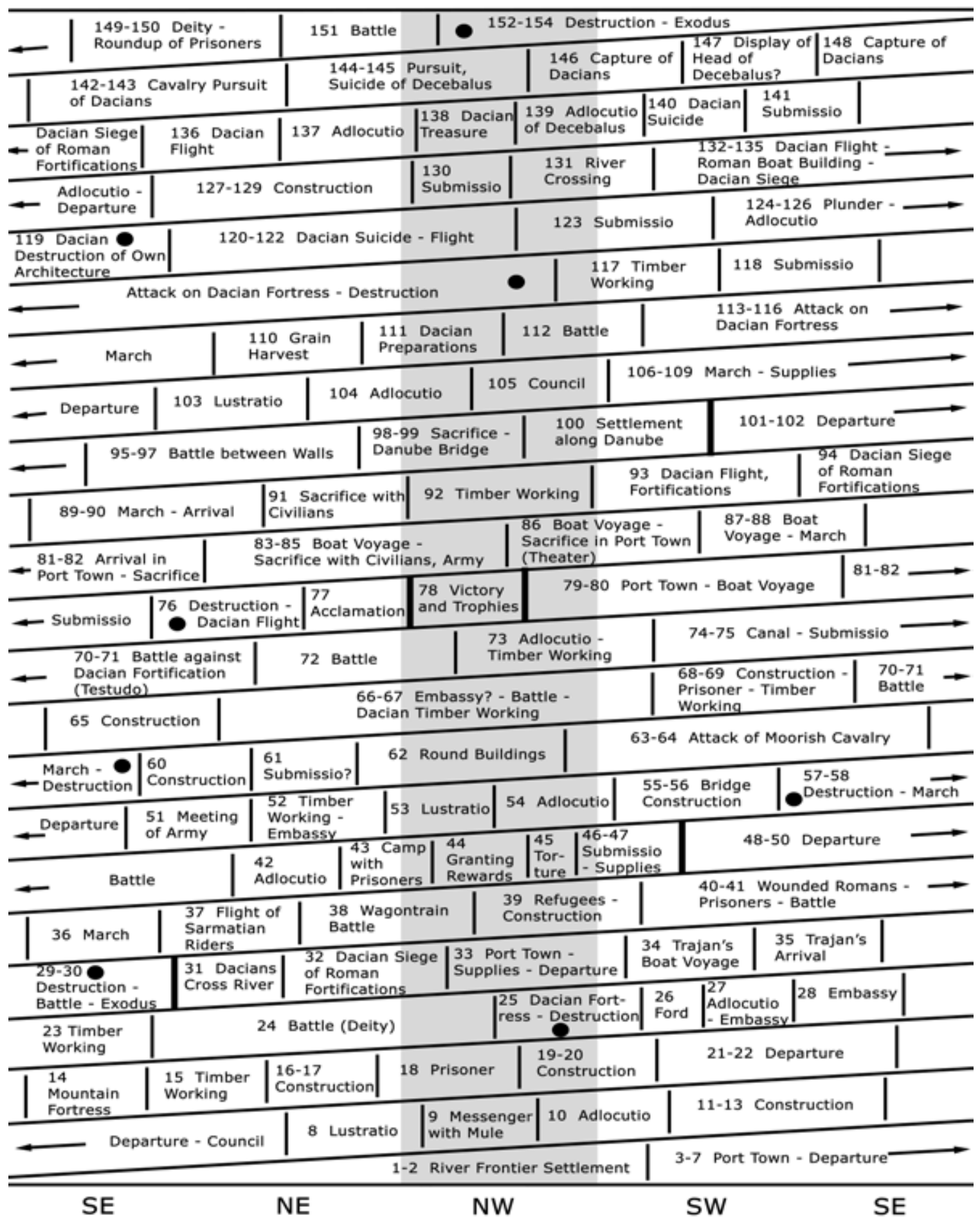

Fig. 2. Positions of destruction sequences along Trajan's Column. Black circles mark depictions of architectural destruction; grey shading marks NW "Victory axis" (diagram's structure and scene divisions follow Baumer et al. 1991, 266 fig. 1; scene labels and markers by author). 


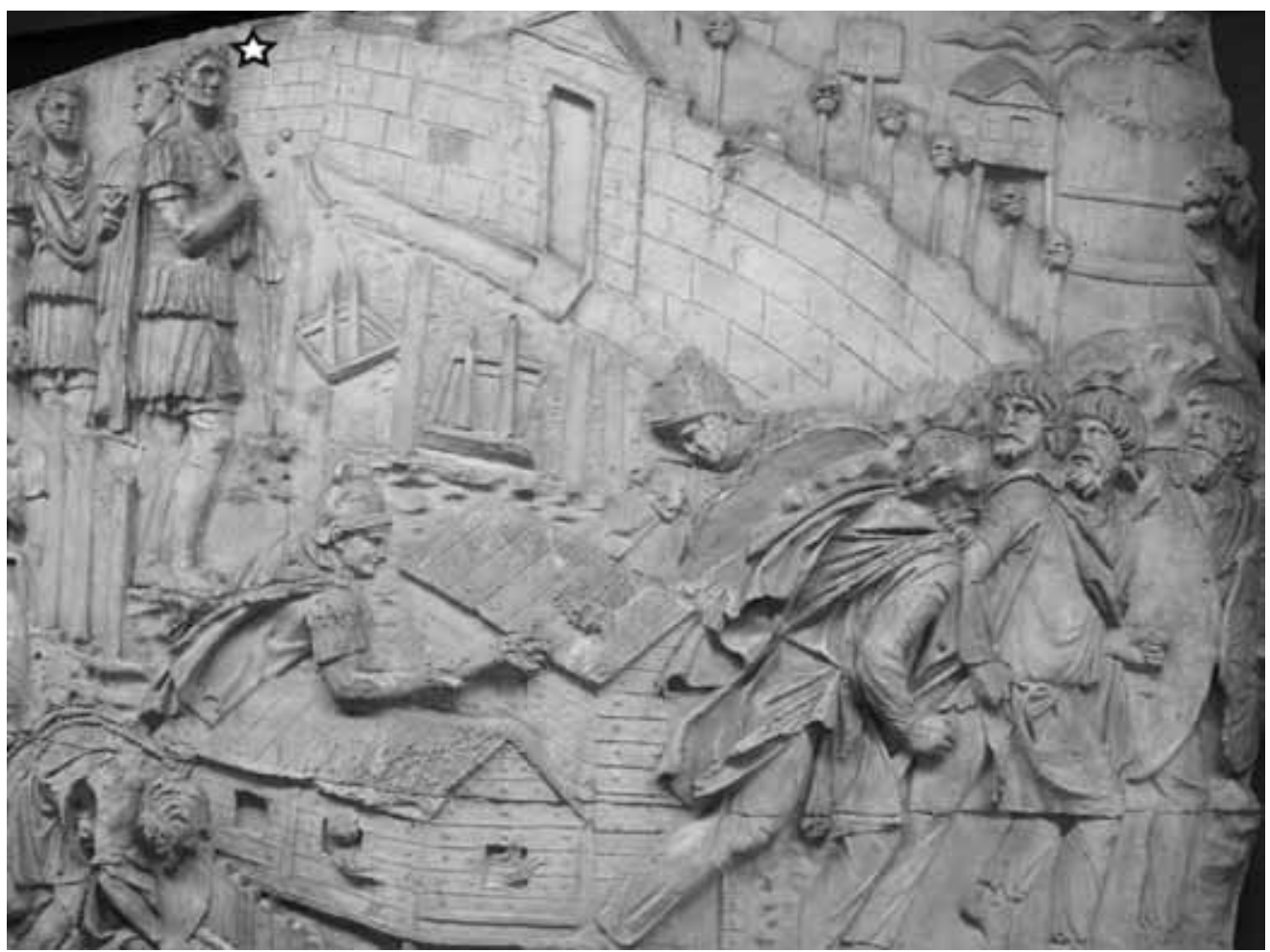

Fig. 3. Trajan's Column, first destruction sequence; star marks Trajan (Scene XXV).

Torches are the primary means of destruction, but pick-axes are also used. Dacian architectural structures under attack include fortification walls and buildings made of both wood and stone. These structures stand alone, in small groups, and also in larger settlements. The overall effect of the variety is to create a complex and comprehensive portrait of the total destruction of Dacian architecture.

The positions of the destruction sequences along the frieze, as well as the relationship between architectural destruction and the emperor, suggest that the motif played an important rôle in the depiction of conquest. ${ }^{22}$ In the first destruction sequence (Scene XXV, figs. 2-3), Trajan is closely associated with the devastation. Although his precise spatial and temporal relationship to the destruction is unclear, his composition is physically overlapped by his soldiers who are burning Dacian buildings. Roman legionaries are the agents of the destruction. The flaming buildings are emphasized as wooden, planks and pegs being clearly delineated (fig. 3). In the second destruction sequence (XXIX-XXX, figs. 2 and 4), Trajan is associated compositionally with the destruction but this time his back is turned to the violence. ${ }^{23}$ Roman auxiliaries replace legionaries as the agents, ${ }^{24}$ and the

costume was intended. For a decrease in differentiation between legionaries and auxiliaries based on costume for the Column of Marcus Aurelius, see Coulston 1988, 384-86; Beckmann 2003, 96 and 179-81.

22 Pirson (1996, 173), for instance, states that "the devastation of barbarian villages ... is in the iconography of Trajan's Column only of secondary importance".

23 This scene is traditionally interpreted as depicting the deportation of Dacian élite women: Lepper and Frere 1988, 76-77; Coarelli 2000, 73.

24 There has been confusion as to the identity of the cavalrymen in Scene XXIX. Lepper and Frere 


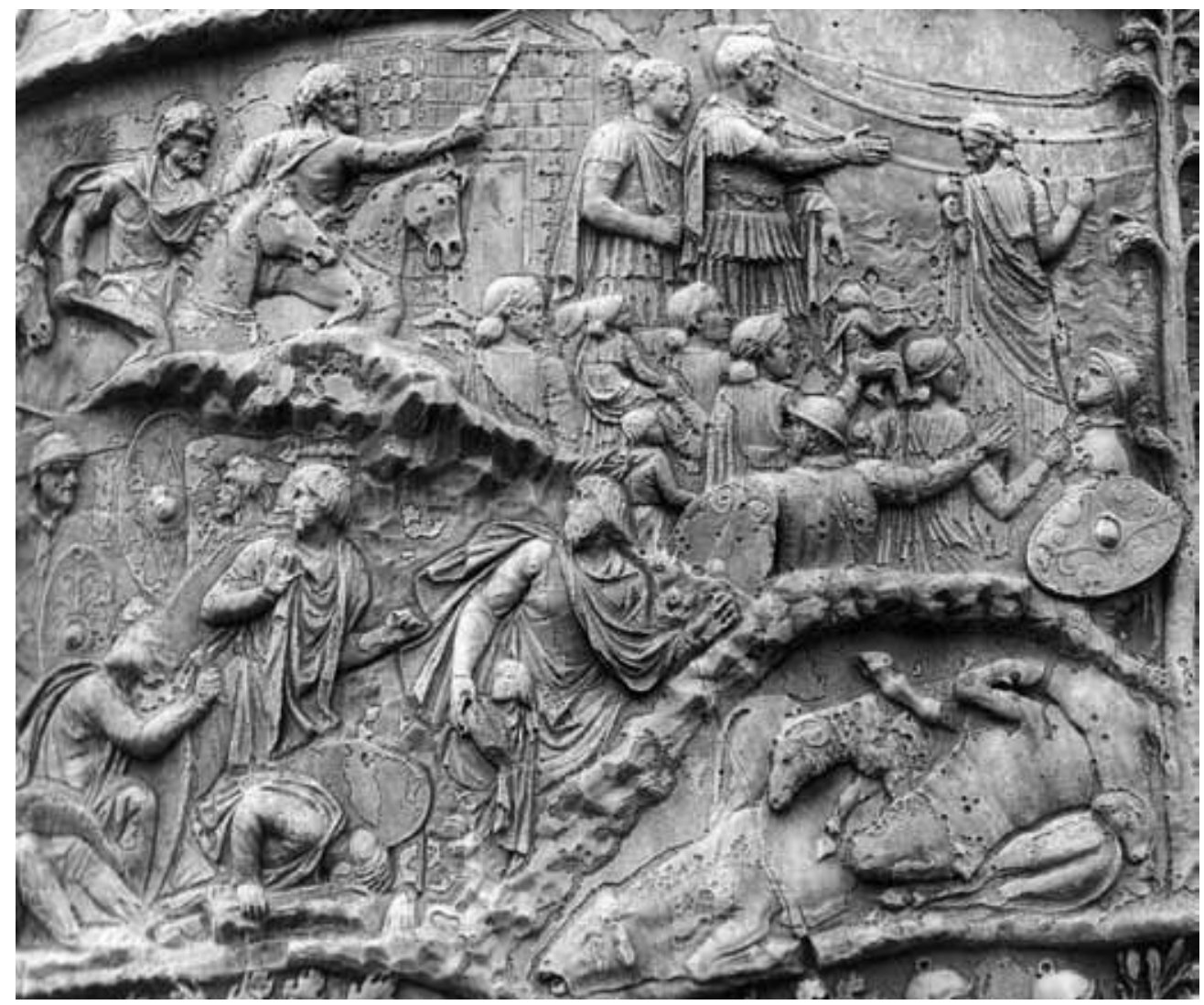

Fig. 4. Trajan's Column, second destruction sequence (Scenes XXIX-XXX; Coarelli 2000, pl. 29).

building whose roof is torched is of stone. In the third destruction sequence (LVII-LIX, figs. 2 and 5-6), Trajan is framed by, but does not participate in, two scenes of Roman auxiliaries burning wooden Dacian buildings. By the fourth sequence (LXXVI), Trajan is clearly separated from the destruction (he appears in the preceding scene LXXV), although he faces and remains the explicit force behind the ruin, since he orders the Dacians to dismantle

$(1988,76)$ and Coarelli $(2000,73)$ identify the figures as auxiliary cavalry, while Koeppel (1991, $158)$ calls the riders Dacian. Coulston, in the most technical analysis (1988, 67-68 and 250), notes that the riders' dress and beards combine features of both barbarians and Roman soldiers while concluding that, whoever the riders are, the narrative indicates that they are on the side of the Romans. The identification of the riders as friendly to the Romans is almost certainly correct, for two reasons. First, if the riders represent an attack on Roman allies, then the complication of the composition of Scenes XXIX-XXX, with multiple, indirectly-related narratives, would be without precedence on the monument. Secondly, Dacians are shown riding horses only three times. The first, directly before the destruction sequence (XXVII), may represent a Dacian embassy, but may also represent barbarians allying themselves with Trajan. None of these barbarians wears pilei; they are received favorably, and perhaps confer with Trajan in the following scene (XXVIII). The other two instances where Dacians ride horses are special circumstances: XXXI, a river crossing (where the horses are in water and only shown partially); and CXLIII-CXLIV, the flight and suicide of Decebalus (where all Dacians wear pilei). Thus the riders in XXIX-XXX should be accepted as allied with the Romans, and, given the prominence of auxiliary cavalry on the column, probably taken as auxiliaries. 


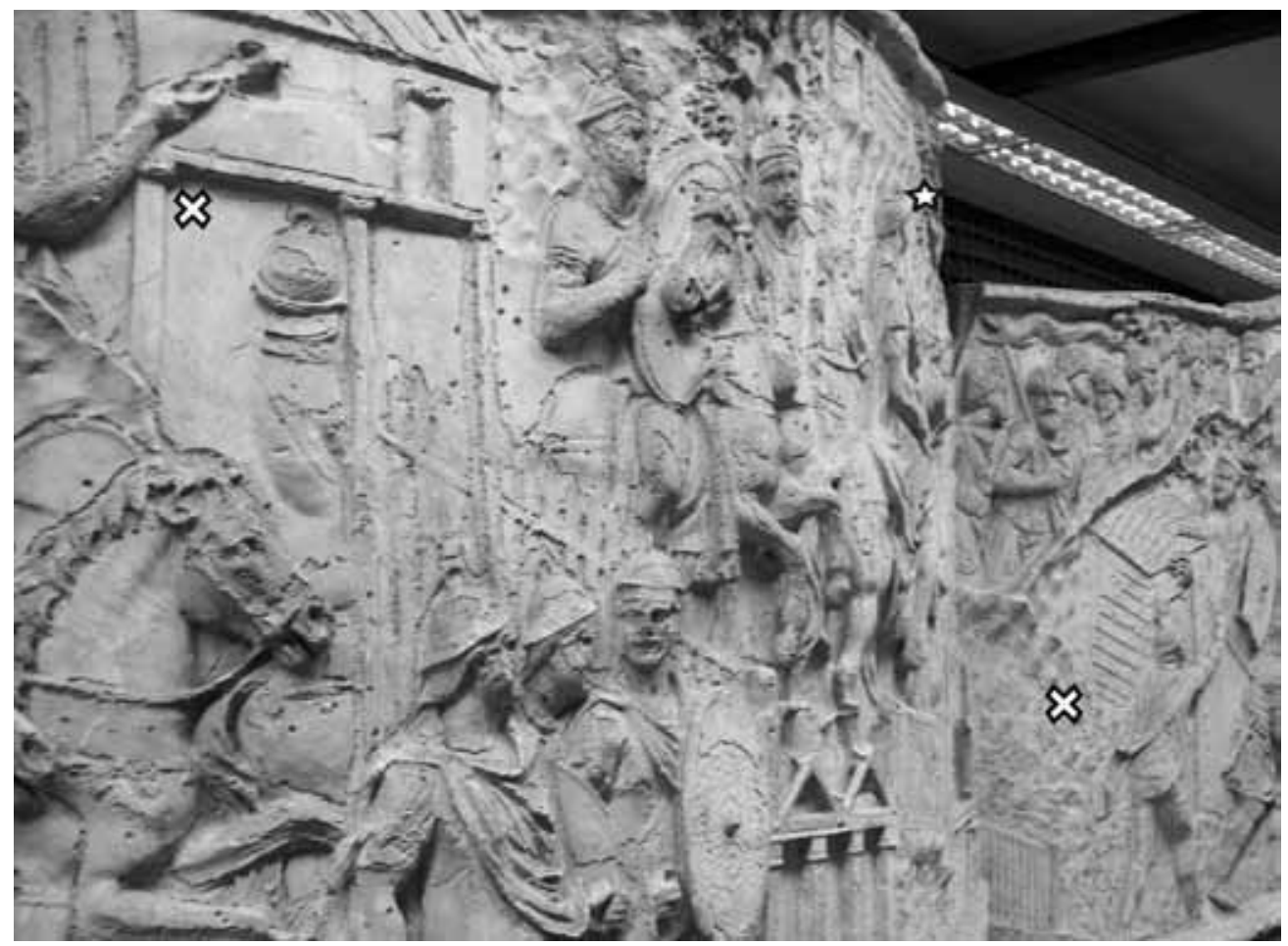

Fig. 5. Trajan's Column, third destruction sequence. 'X's mark Roman soldiers burning buildings; star marks Trajan (Scenes LVII-LIX).

their own stone fortress (figs. 2 and 7). ${ }^{25}$ The distance between Trajan and the destruction is increased in the fifth sequence: Trajan, facing to the left (away from the destruction), appears towards the start of the depicted battle (CXIII; fig. 2). The destruction of the walls of the stronghold by legionaries wielding pickaxes closes the battle several scenes later (CXVI; figs. 2 and 8). The unified narrative event of a single battle is made clear by the winding polygonal walls running across the top of the spiral between scenes, linking Trajan to the destruction. The Dacians possibly participate in the destruction of their own walls in desperate self-defense: two blocks falling on Roman soldiers perhaps have been purposely dislodged and propelled (fig. 8). ${ }^{26}$ In the sixth sequence (CXIX-CXXI; figs. 2 and 9), however, Trajan is completely absent: the Dacians not only burn their own buildings, ${ }^{27}$ but

25 This scene is traditionally interpreted as illustrating the forced dismantling of Dacian strongholds as part of Roman terms for peace at the close of the First Dacian War: Coulston 1988, 23; Lepper and Frere 1988, 120-21; Coarelli 2000, 133. The hands of several Dacians in this scene are carved to accommodate metal tools, which would have been inserted separately (Coulston 1988, 85 n.96; for the phenomenon of metal inserts on the column, see, e.g., ibid. 84-86).

26 In CXXXIV, Romans under siege also throw blocks down on their attackers, but it is unclear where these blocks come from.

27 The illustration of indigenous warriors burning their own buildings recalls, e.g., a passage in Caesar's Bellum Gallicum (5.1-2) where the Helvetii burn their buildings to prevent any hope of returning home. Later in the same work (7.14.5-10, 7.15.1-2, 7.55.6-8, 7.58.6, 7.64.3), the Gauls under Vercingetorix adopt a scorched-earth policy, burning their own buildings and fields to deprive the advancing Roman army of supplies. For debate over the possible relationship among Caesar's commentaries, Trajan's Dacica commentaries, and his frieze, see Coulston 1988, 18-19; id. 1990b, 293; Lepper and Frere 1988, 17 and 25-26; Hölscher 1991b, 292-93; id. 2002, 139; 

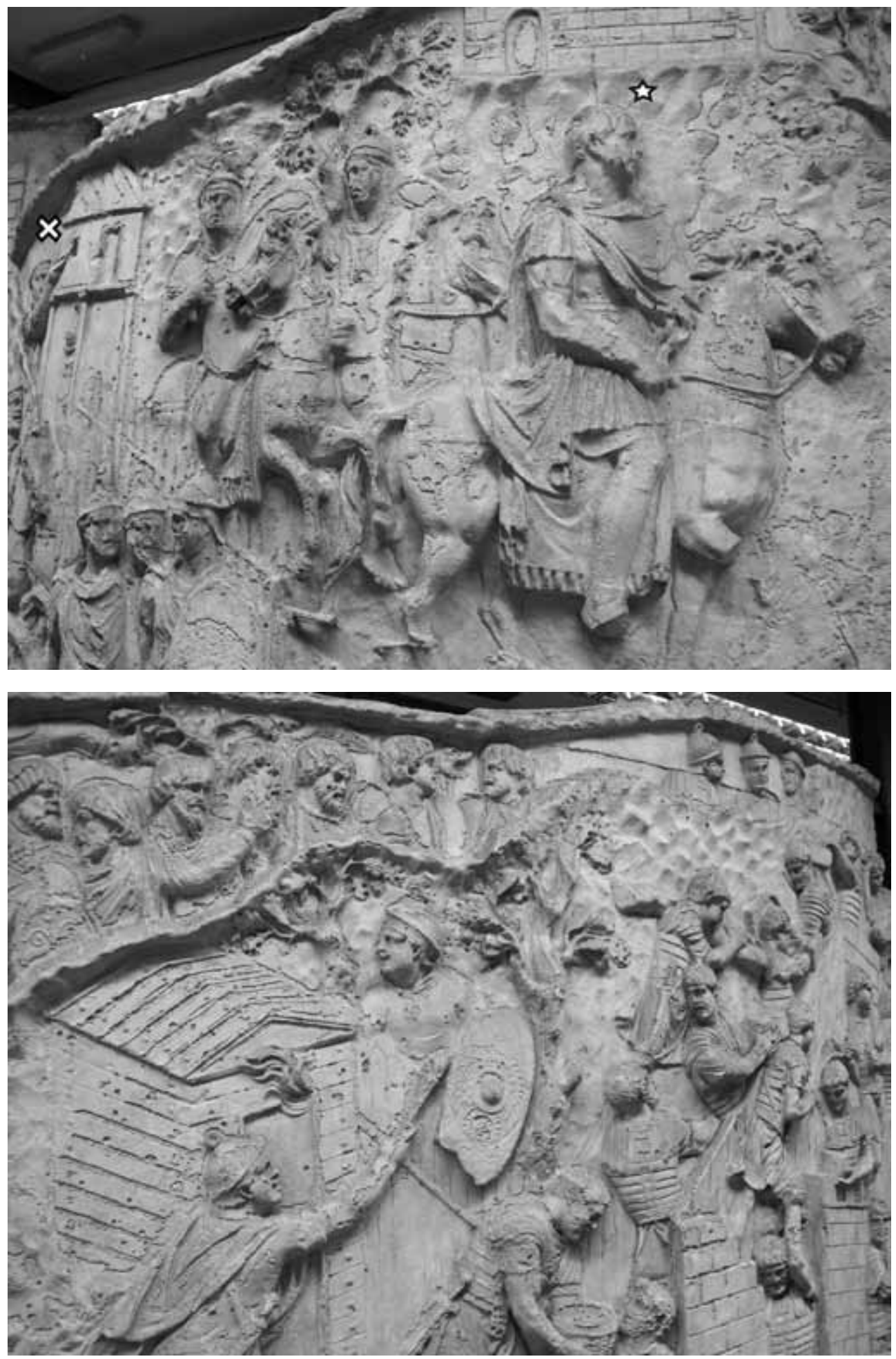

Fig. 6. Trajan's Column, third destruction sequence. Top: Beginning of sequence, ' $\mathrm{X}$ ' marks Roman soldier burning building; star marks Trajan (Scenes LVII-LVIII). Bottom: End of sequence, destruction of Dacian architecture (Scene LIX, left), followed by construction of Roman fortification (Scene LX). Note three legionaries in upper right corner. 


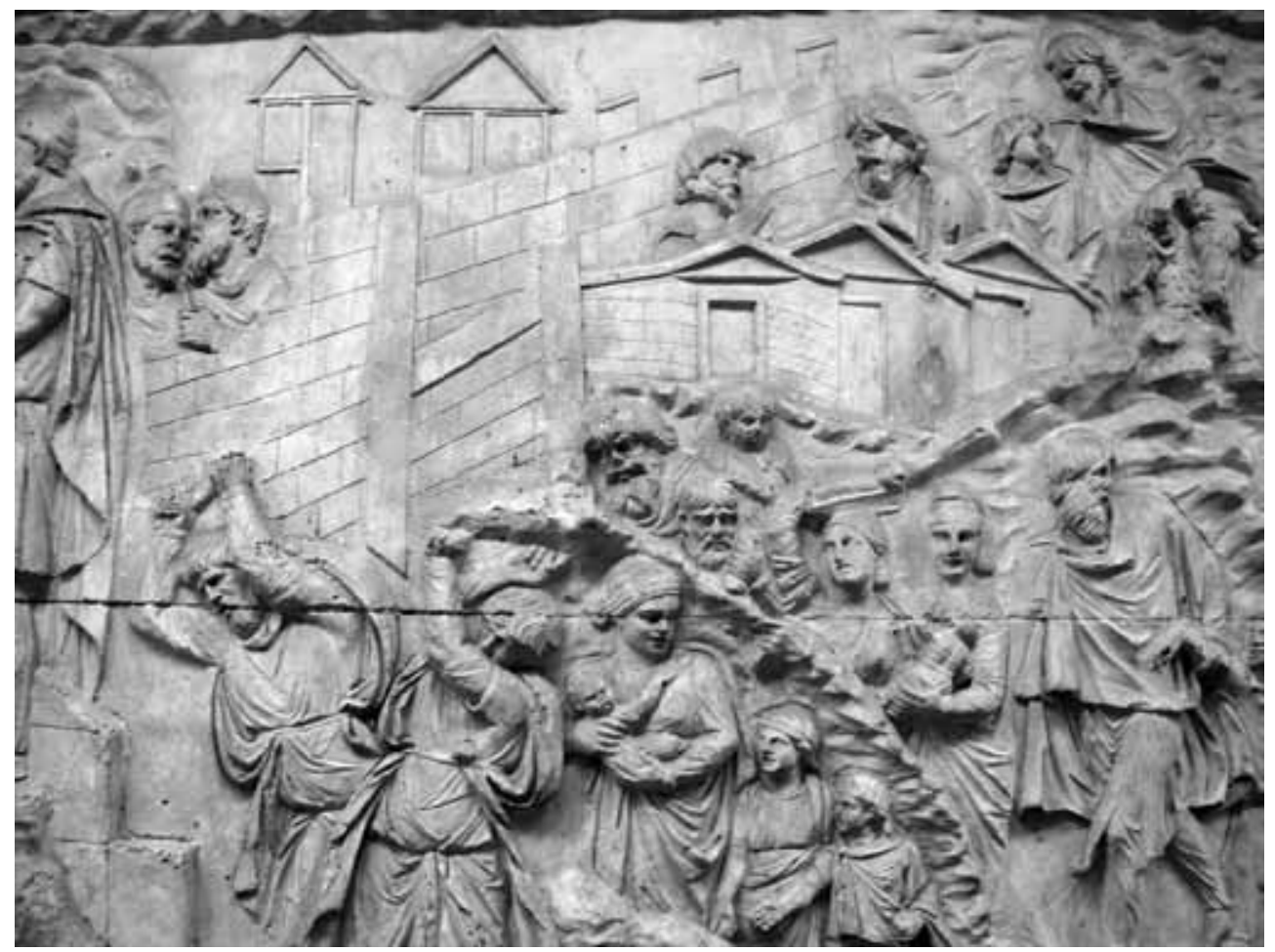

Fig. 7. Trajan's Column, Dacians dismantling fortifications, fourth destruction sequence (Scene LXXVI).

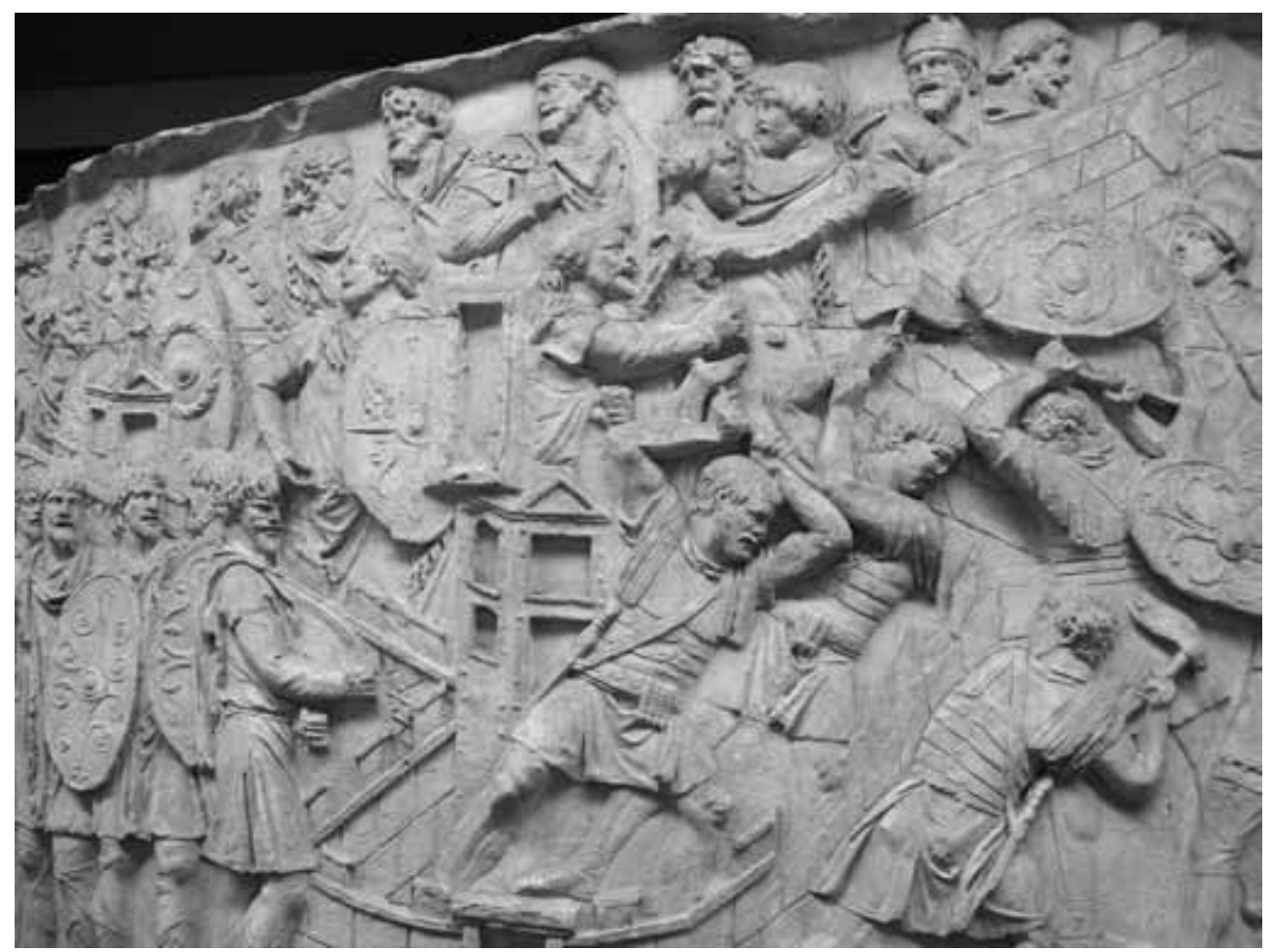

Fig. 8. Trajan's Column, fifth destruction sequence, Roman legionaries dismantling Dacian fortifications. Note change from polygonal masonry with roundels to squared masonry at lower left corner; and falling blocks at upper right corner (Scene CXVI). 


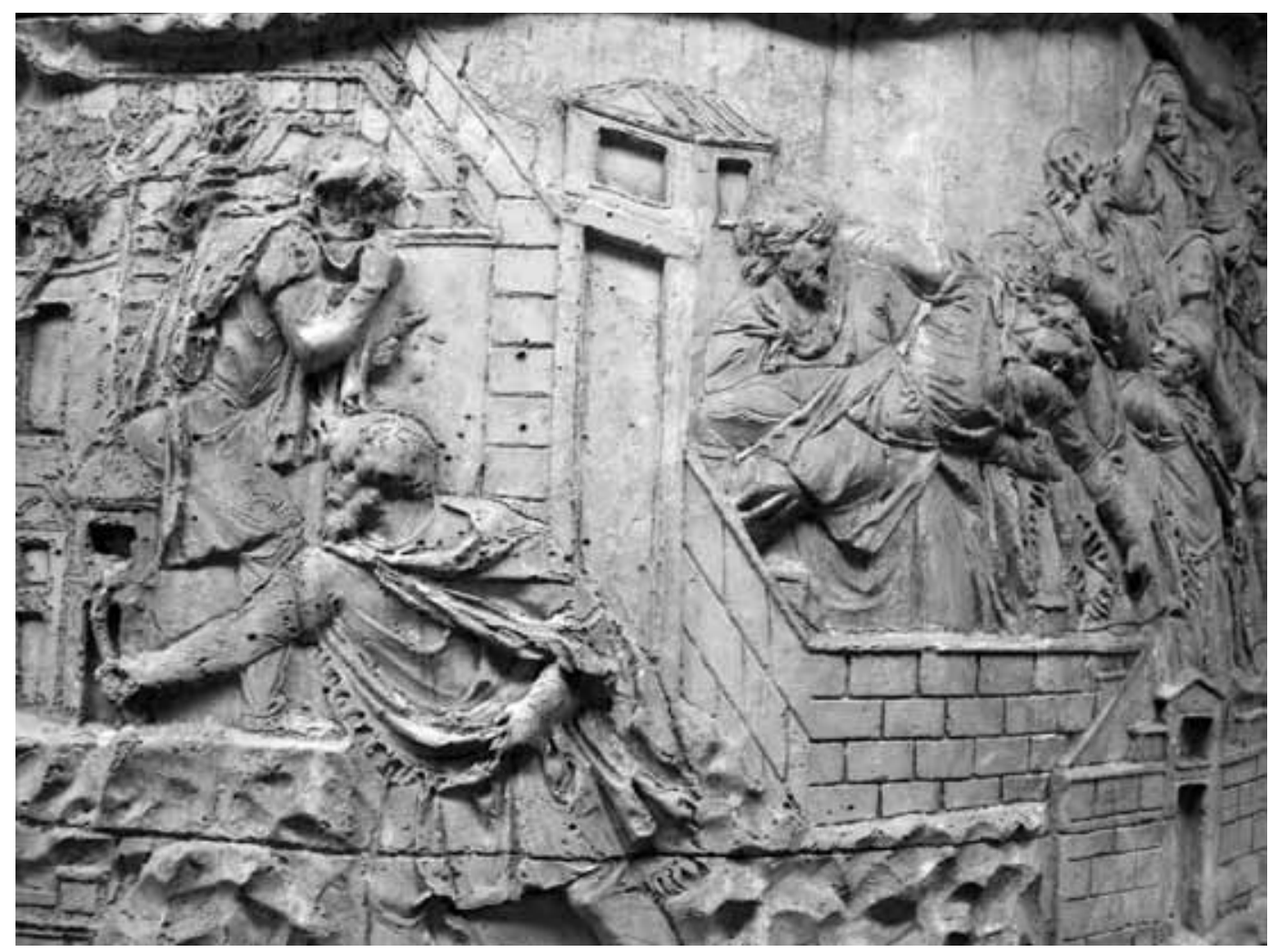

Fig. 9. Trajan's Column, sixth destruction sequence, Dacians burning buildings (left) and committing suicide (right) (Scenes CXIX-CXX).

seemingly commit suicide on a grand scale (fig. 10). ${ }^{28}$ By the seventh sequence at the end (CLII; figs. 2 and 11), torches are raised even to stone buildings as the auxiliaries methodically complete their work of conquest.

The generally increasing distance (both physical and conceptual) between Trajan and the destruction of architecture creates a carefully tempered connection between emperor and destruction. In Scene XXV, Trajan is geographically distanced from, but compositionally connected to, the destruction of indigenous architecture (fig. 3). Although he does not participate directly in its destruction, he obviously condones such practices. This connection, established in the first destruction sequence, ensures that Trajan's presence is felt throughout all the destruction sequences, even as he becomes more distanced. In this first sequence, the close relationship between the emperor and destruction, as well as his use of legionaries as the agents, establishes architectural destruction as an appropriate tool in

Coarelli 2000, 13.

28 Scene CXXI is traditionally interpreted as illustrating the doling out of poison amongst the Dacian élite (Coulston 1988, 21, 23-24 and 29; id. 1990b, 297; Hölscher 1991b, 293; Koeppel 1992, 96-97; La Rocca 1994, 27; Coarelli 2000, 192; Diaconescu 2004, 122-23; Haynes and Hanson 2004a, 14), although some have taken it as the distribution of the final water rations following a siege (for full discussion, see Lepper and Frere 1988, 168-69). Suicide seems to be the more probable scenario, since ancient art had little (extant) precedent for visually depicting logistical issues like running out of water under siege. In any event, the outcome is obvious in the sprawling Dacian bodies. 


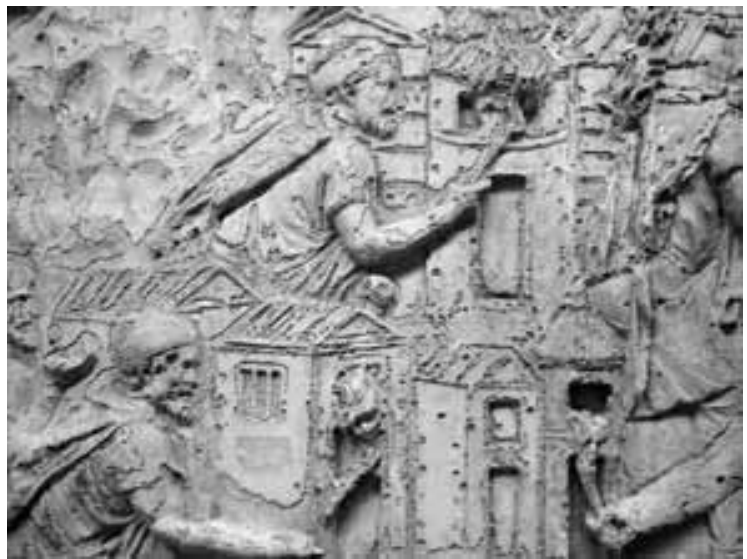

Fig. 10. Trajan's Column, sixth destruction sequence. Left: Dacians burning Dacian buildings (Scene CXIX). Right: Dacians drinking poison (Scene CXX).
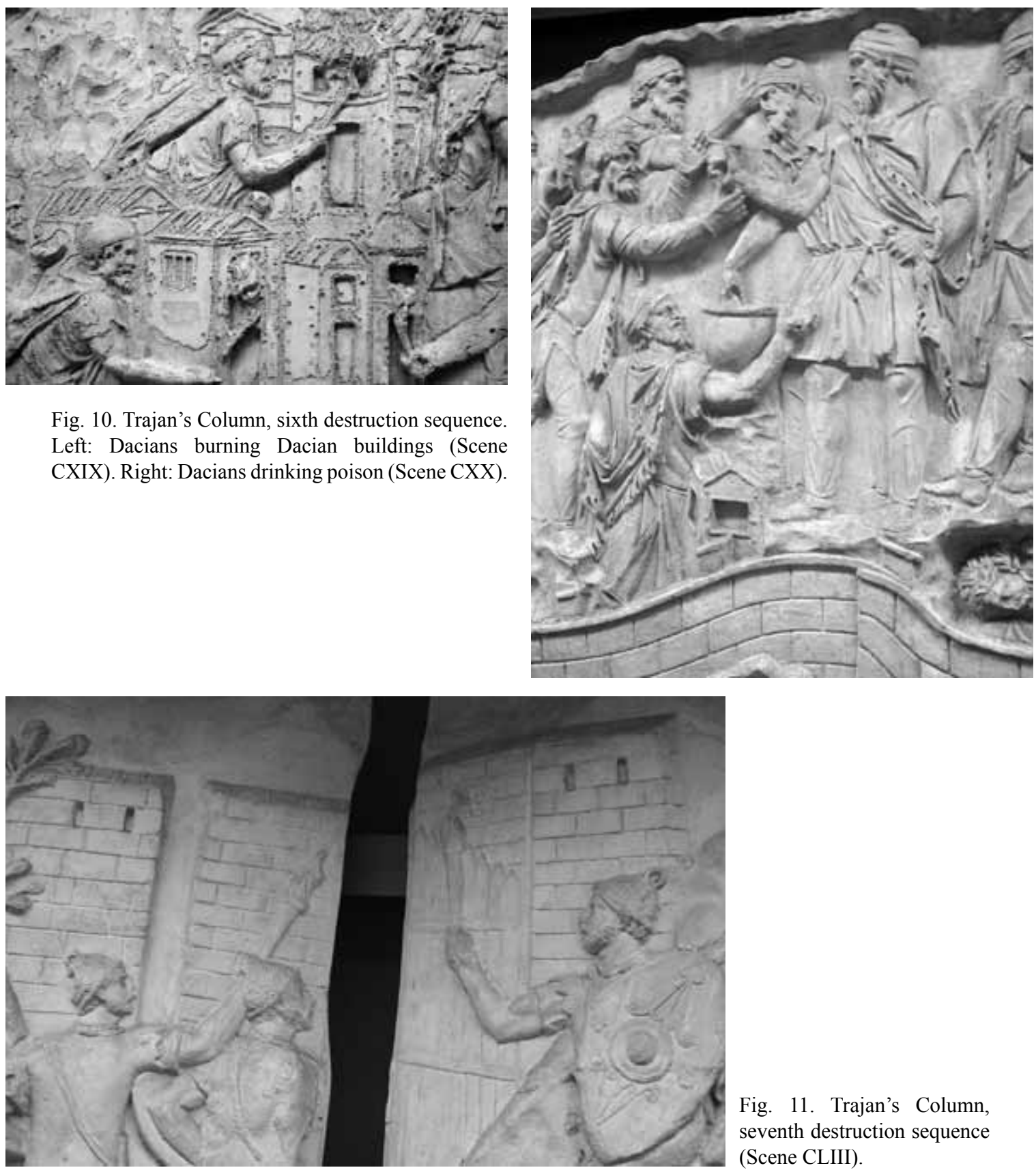

Fig. 11. Trajan's Column, seventh destruction sequence (Scene CLIII).

the army's war chest. But the increasing distance between Trajan and the destruction and the increased use of auxiliaries and eventually Dacians as the agents of destruction show that burning primitive Dacian structures was not the chief logistical concern for the finest elements of Rome's army. ${ }^{29}$ Architectural destruction is introduced as an activity that is

29 For a similar argument regarding the physical annihilation of the Dacian people on the column, see Pirson 1996, 173. The only other clear instance where legionaries are used as the agents of destruction is in the fifth destruction sequence (CXVI), where the context is battle and the task is to destroy the fortification walls that have contributed to barbarian resistance and a prolonged 
approved of by the emperor, albeit from a distance and one that, to a limited extent, can be undertaken by legionaries.

Even if this kind of destruction is not the army's chief logistical concern, the importance of architectural destruction is clear from its narrative and physical positions within the frieze (fig. 2). Scene XXV not only follows XXIV, the first depiction of battle, but also includes the first depiction of Dacian architecture. After the introduction of indigenous architecture, its destruction follows as a natural consequence of victory. ${ }^{30}$ The positioning of Scene XXV in particular suggests that architectural destruction was seen as a motif worthy of emphasis. This scene comes in the fourth spiral, low enough that it could have been seen well from ground level (fig. 2). T. Hölscher and S. Settis have argued that the lower spirals acted both as a sort of thematic summary of the rest of the frieze and as an assurance that the same sort of glorious narrative visible to the naked eye in the lower spirals continued for the height of the column. ${ }^{31}$ Scene $X X V^{\prime}$ 's position within this narrative summary, along wich the exaggerated size and the details of the burning buildings and legionaries, implies that the architectural destruction was meant to be understood as an important part of the frieze's narrative.

Scholars have long recognized that the narrative and layout are organized around the shaft's cardinal axes, with thematic linkages connecting crucial scenes along a given vertical axis. The first destruction sequence (XXV) appears along what scholars have identified as the 'Victory axis' (fig. 2). ${ }^{32}$ This axis along the NW side included such scenes as the initial crossing of the Danube (III-IV), the Victory marking the end of the First War (LXXVIII), Apollodorus's bridge over the Danube (XCVIII-C), the capture of Decebalus' treasure (CXXXVIII), and, at the top, his suicide (CXLV). The presence of the first destruction sequence along this axis provides support that architectural destruction was an important component of the column's message, while the same axis includes the fifth destruction sequence (CXVI) and is capped by the seventh (CLII). Most of the other destruction sequences are arranged around the opposite (SE) axis.

\section{Architectural destruction and cultural obliteration}

Such destruction is not only a logistical means to achieve military victory: it is a symbol of cultural victory in Dacia. In several scenes the destruction of Dacian architecture is equated through the composition with the destruction of Dacian culture as a whole.

siege (CXIII-CXVI). In this instance there seems to have been some interest in demonstrating the difficulty of the task. Throughout the rest of the battle, the Dacian fortress is shown with polygonal lines interspersed with double rows of roundels, the first and last appearance of polygonal construction on the frieze (for discussion of this rendering and its possible connection to the murus Dacicus, see Coulston 1988, 153-54; id. 1990a, 47; Lepper and Frere 1988, 165), but just before its destruction the construction material shifts to be represented by rectangular hatching, in the manner of masonry blocks.

30 From the standpoint of military logistics, the burning of settlements often preceded an assault on a fortress, in order to draw out the enemy (my thanks go to one of the reviewers for drawing this to my attention). Regardless of where on the frieze the narrative of one assault ends and another begins, however, reading left to right the depiction of destruction immediately follows that of victory.

31 Settis 1988, 109-10; id. 2005, 74-75; Hölscher 1991a, 263-64; id. 2000, 90-91; id. 2002, 139-40.

32 For recent discussion, see, e.g., Coulston 1988, 30-32 and 35; id. 1990b, 299; Hölscher 1991b, 29091; Coarelli 2000, 19; Koeppel 2002, 250; Settis 2005, 79; Galinier 2007, 85-88. 
In the second sequence (XXIX-XXX), architectural destruction takes its place alongside deported women and children, fleeing men, and rotting animals, in a chiastic arrangement illustrating the downfall of Dacian culture (fig. 4). ${ }^{33}$ In the sixth (CXIX-CXXI), a fortification wall serves as the compositional axis, with the burning of Dacian architecture at Dacian hands on one side (CXIX), paralleling the destruction of the Dacians themselves at their own hands on the other (CXX) (figs. 9-10). ${ }^{34}$ The seventh sequence (CLII) follows the last scene of battle, and is in turn followed by the final scene of deportation (CLIVCLV) (fig. 2). The destruction of Dacian architecture both illustrates and stands in for the destruction of Dacian culture.

As barbarian culture in Dacia is being destroyed, Roman civilization in Dacia is being born. Architecture plays an important rôle in this contrast. Both Romans and Dacians are shown burning buildings, but while Dacians only destroy or abandon their buildings, or defend them in vain, Roman soldiers construct new architecture. The Roman army is constantly portrayed in the process of constructing new bridges, roads, and stone fortifications (fig. 2). ${ }^{35}$ The only instance in which any Dacian attempt at construction is even implied is in Scene LXVII, ${ }^{36}$ and it is wooden construction. ${ }^{37}$ This contrast is vividly illustrated in the third sequence (LVII-LIX), paired with and overlapped by a scene (LX) of Roman building where legionaries construct a fortification (figs. 2 and 5-6). The parallelism is heightened by the upper register: above the burning Dacian buildings in LIX, a large group of Dacians gesture in despair as they look towards the rising Roman fortification to the right (LX); similarly set above the Roman construction, three somewhat oddly positioned legionaries glance towards the fire. The chiastic arrangement of large, bareheaded groups with the smaller, helmeted detachments encourages comparison.

A similar comparison between destruction and construction can be seen in the fifth destruction sequence (CXVI) where, however, the construction materials are reversed: Roman legionaries destroy stone architecture (CXVI), while in the next scene (CXVII) they chop down trees and assemble neat piles of logs (figs. 2 and 8). Similar piles of logs are associated with the construction of boats by legionaries in CXXXIII, as well as with Rome's mastery of siege equipment in LXVI and LXXV. Although the motif is not as developed as in the third sequence, the fifth continues the contrast between the destruction of Dacian and the construction of Roman architecture. ${ }^{38}$

33 A chiastic arrangement is a common form of composition, whereby 4 inter-related elements are arranged in the shape of the Greek letter chi (or the English X). This composition links the 4 elements visually and conceptually, while maintaining each element as a separate entity. Often elements in opposite corners (e.g. upper left and lower right) share a special connection. In the second destruction sequence, the vignettes involving actions towards people are in opposite corners from each other; the same can be seen for the vignettes involving the destruction of the indigenous landscape (including architecture).

34 Wolfram Thill 2010, 38.

35 For discussion of the importance of the depictions of Roman construction activity on the frieze, see, e.g., Richmond 1982; Lepper and Frere 1988; Coulston 1990a; Coarelli 2000; Wolfram Thill 2010. For debate over whether stone construction is depicted, see supra n.16.

36 Lepper and Frere 1988, 105; Hölscher 1991b, 291; Coarelli 2000, 118.

37 Hölscher 2002, 137.

38 The parallels between destruction of Dacian and construction of Roman architecture may shed light on a confusing narrative episode on the frieze. Scenes XCV-XCVI seem to depict a battle between parallel stone fortification lines, with the next scene (XCVII) showing soldiers working the ground with pickaxes and chopping down trees, perhaps clearing a road (Rossi 1968; 


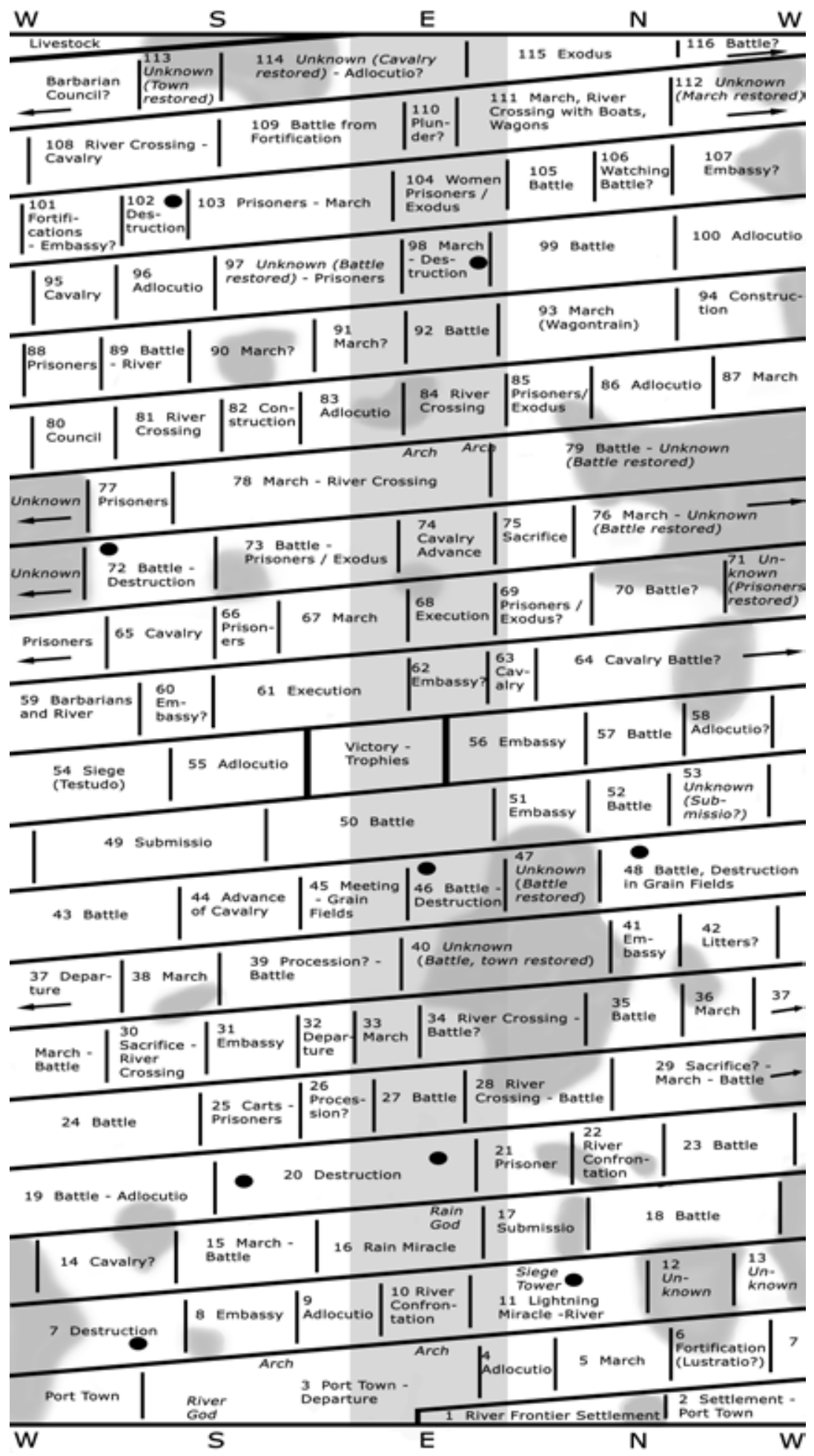

Fig. 12. Column of Marcus Aurelius, positions of destruction sequences. Black circles mark depictions of destruction, light grey shading marks E "Victory axis", dark grey shading marks areas of damage and/or reconstruction (diagram structure, scene locations and damaged areas follow Beckmann 2003, fig. 1.5; scene labels and markers by author). 
In short, the employment of architecture on Trajan's Column to characterize and contrast participation in Roman and Dacian cultures is not limited to building types or contrasting construction methods. The birth and death of architecture, vividly depicted, play a rôle. On Trajan's Column, indigenous Dacian architecture can stand in for indigenous Dacian culture as a whole, illustrating the obliteration of those who dare to resist Rome. That this equation between architecture and culture is most evident in the architecture's destruction meant that the message of the destruction sequences would be self-evident: choose resistance, and your culture will perish.

\section{Architecture and its destruction on the Column of Marcus Aurelius}

The most obvious point of comparison for Trajan's Column is its direct descendant. Poorly preserved and heavily restored at some points (fig. 12), ${ }^{39}$ and lacking complete, readily-available casts, the architectural depictions of the Column of Marcus Aurelius do not lend themselves to precise quantification. Nevertheless, a systematic survey of all of the architectural depictions can reveal broad trends that illustrate the monument's treatment and use of architecture. ${ }^{40}$

The frieze preserves 38 probable assemblages of built structures and 2 possible ones. ${ }^{41}$ Seven further scenes (Scenes VIII, XV, XIX, XXI, XXXI, XXXIX, LX) feature large Roman tents, in three cases (VIII, XXXI, XXXIX) paired with what seems to be a vallum..$^{42} \mathrm{~A}$ final

Coulston 1988, 148; id. 1990a, 42 and 44; Lepper and Frere 1988, 146; Hölscher 1991b, 291; Coarelli 2000, 160). At the junction between the two scenes, three legionaries seem to be striking the rightmost fortification line with pickaxes. I have not treated this episode as a destruction sequence because there is no consensus as to what these scenes are supposed to depict - whether the walls are meant to be Roman or Dacian constructions, and whether the soldiers are destroying the walls or, having been surprised while constructing a new fortification, are defending themselves (Coulston 1988, 141; id. 1990a, 41; Lepper and Frere 1988, 145; Coarelli 2000, 158-59). These three scenes, however, share many features with some destruction sequences. In particular, XCVI and CXVI are the only two instances where soldiers are shown using dolabrae (pickaxes) in battle (Coulston 1988, 92), both occurring to the far right of a longer scene of some kind of siege. Just as with the third and fifth destruction sequences and their succeeding scenes of construction, XCVII-XCVIII feature a contrast between destruction and construction, as well as in wood versus stone. While none of these parallels is conclusive, the most convincing interpretation of XCVI-XCVII may be that Roman soldiers destroy Dacian stone architecture and then proceed to construct new architecture. Scene XCVI would then depict a Roman assault on Dacian defensive constructions.

39 This can be clearly seen in Coarelli 2008.

40 For my survey I relied on Coarelli's 2008 edition of photographs in combination with my own photographs taken from ground level (here figs. 17-18).

41 Probable assemblages of built structures: Scenes I-III, VI-VII, XI, XVIII, XX, XXIX, XXXVII, XLIII, XLVI, XLIX (2 separate assemblages), L, LIV-V, LXXI, LXXV, LXXVIII, LXXX, LXXXII, LXXXIV, LXXXVI, LXXXVIII-IX, XCIV-V, XCVIII, C-CII, CIV-VII, CIX/CX-CXI. Possible assemblages of built structures: $X \mathrm{~L}$ and CXIII. Scene $\mathrm{XL}$ is heavily restored: in its present state it shows a battle taking place in front of an urban architectural backdrop. A composition combining battle and an elaborate town is unusual and not found elsewhere on either column. Scene CXIII is heavily restored: in its current state it seems to show a river rushing through a fortification. Again, this has no real parallel on either column, although it may be a confused combination of the canal and possible reservoir/fortification in Trajan's Column scene LXXIV. It is unclear whether or to what extent the restorations on the Column of Marcus Aurelius preserve original motifs.

42 Hanoune 2000, 210. He includes tents in his list (206) of Roman architectural types on the Column of Marcus Aurelius. 
scene (CXV) shows a boat bridge without a parapet. ${ }^{43}$ There are thus 40 probable or possible assemblages with built architecture, while 8 additional assemblages imply Roman occupation through ephemeral structures. Within these 48, I was able to distinguish 51 separate built structures and 18 tents (all other structures were too poorly preserved to be enumerated).

Architecture is much less important on the Column of Marcus Aurelius than it is on Trajan's. ${ }^{44}$ This is clear from the sheer numbers of structures depicted: on the Column of Marcus Aurelius the number was probably 75 at most (including tents), as against 384 on Trajan's. ${ }^{45}$ The differences also extend to thematic aspects. While on Trajan's the numerous construction scenes emphasize the permanence of the Roman presence in Dacia, ${ }^{46}$ the $^{6}$ Column of Marcus Aurelius features only two depictions (Scenes LXXXII and XCIV) of military building activity. ${ }^{47}$ In both of the two forts under construction, hatching indicating stone construction is lacking. In several scenes on this column military occupation is represented only through tents. The theme of the Roman military establishing a permanent, physical presence in barbarian territory through the construction of stone fortifications, a theme so important for Trajan's Column, is nearly absent from its successor. ${ }^{48}$

Important thematic distinctions between the columns are also found in the depiction of indigenous architecture. Of the 40 architectural assemblages on the Column of Marcus Aurelius, twelve include unambiguous indigenous architecture (Scenes VII, XI, XX, XLIII, XLVI, LXIV, LXXI, LXXXVIII, XCVIII, CII, CIV, and CX). All of it is presented as simple

This imagery is without parallel on Trajan's Column. Both boat-bridges there (IV-V, XLVIII) include built parapets. Scene CXXXI features a plank bridge without a parapet.

Coulston 1988, 383; Pirson 1996, 140, who (149) attributes the reduced inclusion of architecture in part to a desire to clarify the action without the distraction of architecture in the background; Hölscher 2000, 96; Grunow 2002, 134; Beckmann 2003, 197. Trajan's Column: 326 permanent structures plus 58 tents.

46 Wolfram Thill 2010.

47 Coulston 1988, 383-84; Pirson 1996, 140; Hanoune 2000, 207-8; Grunow 2002, 134; Kovács 2009, 175; Beckmann 2011, 162. Scene XCVIII has also been taken (Coulston 1988, 383-84; Ferris 2009, $153)$ as a depiction of military construction; Beckmann $(2011,162-63)$ connects it to the other depictions of military construction, but notes that it is "distinctly novel in both carving and compositional style". Scene XCVIII is better interpreted as showing destruction, for several reasons:

(a) the pose of the soldiers in XCVIII is more aggressive and less varied than those seen in the two undisputed construction scenes;

(b) in these two construction scenes, the soldiers wear segmented armor without helmets, while in XCVIII the soldiers wear helmets but no segmented armor;

(c) the two construction scenes feature a generally open composition, while the composition of XCVIII is closed, with two soldiers turning their backs to the viewer;

(d) no fortification is shown in XCVIII. While it is possible that XCVIII is meant to depict timber working, there are no logs comparable to those in LXXXII and XCIV.

In the end, the closest parallel to the composition and poses of XCVIII can be found in the legionaries attacking the Dacian fortification in Trajan's fifth destruction sequence (CXVI): this scene also features a group of soldiers in a tight, inward-facing group, all with pick-axes raised above their heads, and with one turned so that his back is facing the viewer. Scene XCVIII on the Column of Marcus Aurelius does not specify what is being destroyed, but the presence of a barbarian hut indicates that the destruction is meant to be understood as directed towards architecture.

48 The lack of military construction on the later column may reflect some reality of Marcus Aurelius's campaigns, perhaps their lack of emphasis on establishing permanent settlements, but the lack of military construction was still a compositional choice. 


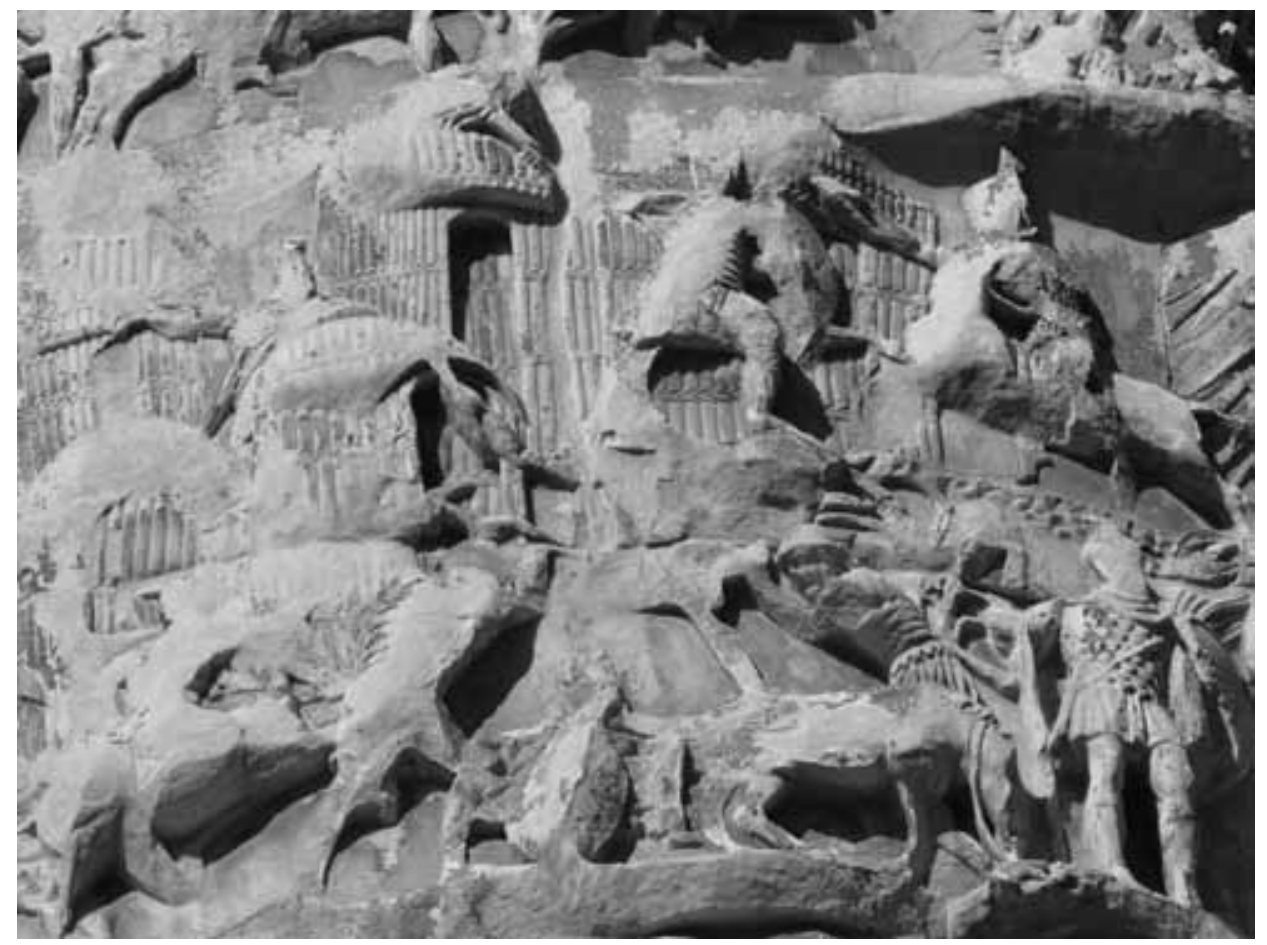

Fig. 13. Column of Marcus Aurelius, indigenous huts and their destruction (Scene VII; E. C. Robinson).

reed or wooden huts (fig. 13), ${ }^{49}$ except for a wooden siege-tower in the Lightning Miracle $\left(\mathrm{XI}{ }^{50}\right.$ fig. 14) and a wooden fortification $\left(\mathrm{LIV}^{51}\right)$.

Difficult to categorize is the house in Scene I that is built of wood or some organic material (fig. 15). Since it is a unicum and appears in an area that has received the Romans, it probably should not be considered purely indigenous architecture in the same vein as the huts or fortification of LIV; 52 instead, it may mark an attempt to capture the alien world of this frontier.

The later column's depiction of indigenous architecture primarily as primitive huts is in direct contrast to Trajan's, where indigenous architecture is always represented as built structures, albeit often of wood or simple stone, or even as stone fortifications. Regardless of how closely the depictions of architecture on the two columns reflect actual architectural practices in the different areas beyond the Rhine and Danube, this difference results from a significant compositional choice.

49 Drexel 1918; Behn 1919a, 53-54; Hanoune 2000, 206 and 209; Hölscher 2000, 98. For discussion of the exact construction material implied for the huts, see Behn 1919a, 52-53; Ferris 2009, 156.

50 For a detailed discussion of this scene's narrative and significance, see Kovács 2009, 137-68; also Hölscher 2000, 99-100; Beckmann 2003, 38; id. 2011, 133-40; Clarke 2003, 47; Dillon 2006a, 262; Coarelli 2008, 50-51; Ferris 2009, 156. Hanoune $(2000,206)$ does not include the siege tower in his categorization of indigenous architecture on the Column of Marcus Aurelius.

51 Hölscher 2000, 99; Ferris 2009, 157; Beckmann 2011, 100-2. The exact material of this fortification is not clear, but it is not stone (it is some ephemeral material).

52 Hanoune $(2000,206)$ includes this building in his categorization of indigenous architecture on the Column of Marcus Aurelius. 


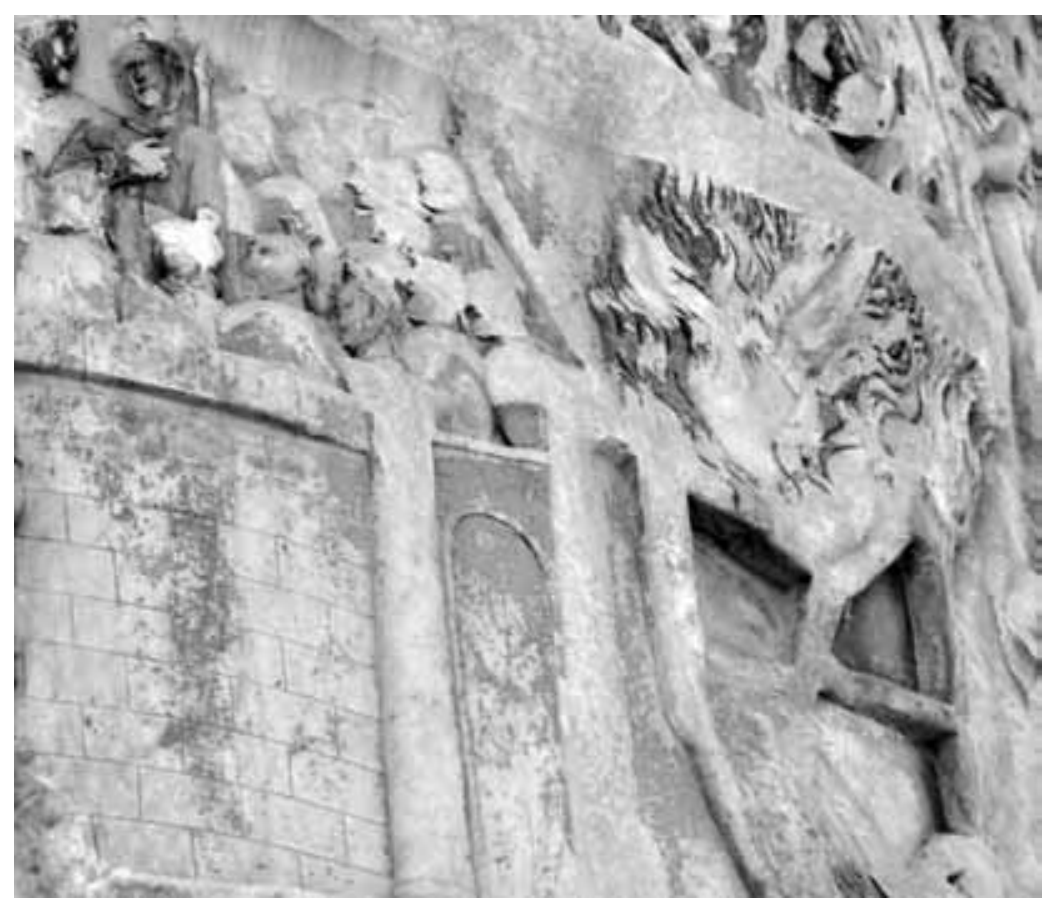

Fig. 14. Column of Marcus Aurelius, destruction of barbarian siege engine by lightning ("Lightning Miracle") (Scene XI; E. C. Robinson).
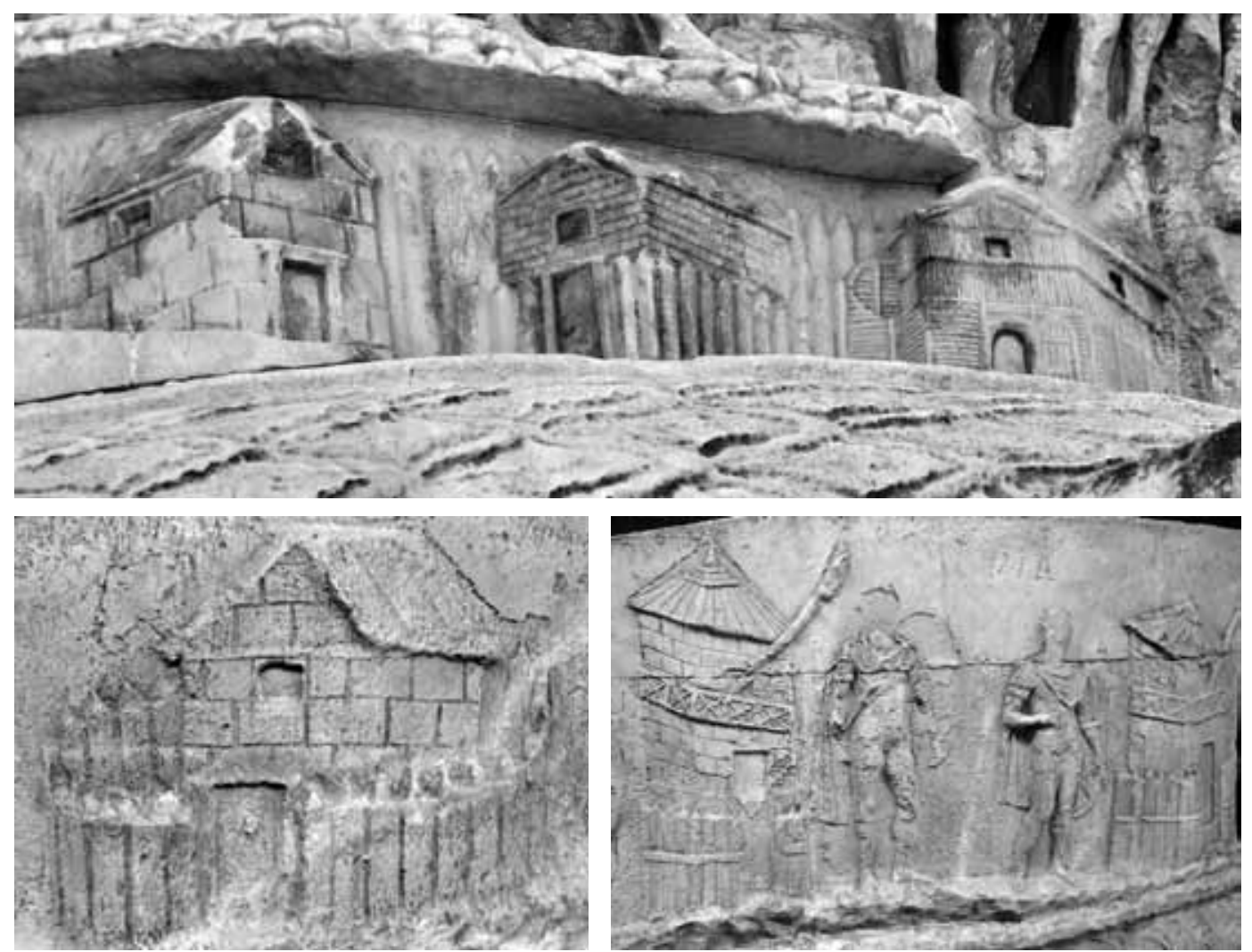

Fig. 15. Frontier settlements along river. Top: Column of Marcus Aurelius, Scene I. Note wood/reed house at far right (E. C. Robinson). Below: Column of Trajan, Scene I. 


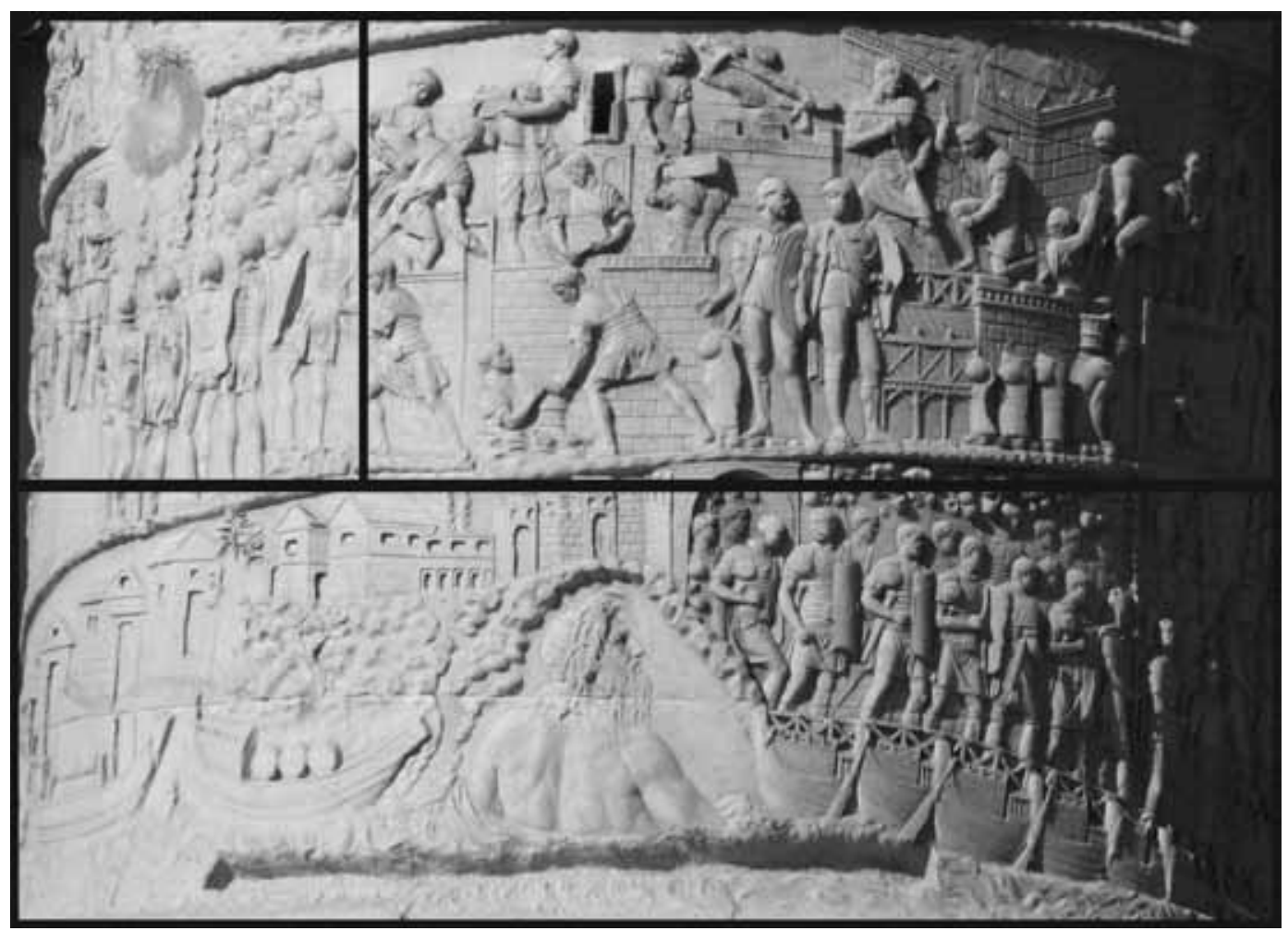

Fig. 16. Trajan's Column, use of architecture on two lowest spirals. Upper left: emperor and group; upper right: construction of new Roman architecture; below: river god and settlement (author).

Simplistic barbarian architecture and the near-absence of military construction may both be better understood through the arguments of F. Pirson, who suggests that, in contrast to Trajan's, the Column of Marcus Aurelius portrays the Roman army as victorious through inevitable superiority, triumphing without effort over a patently inferior enemy..$^{53}$ The reduction in military construction can be interpreted in light of the column's general lack of emphasis on the technical expertise displayed by the army; such proficiency is not needed against a primitive enemy. ${ }^{54}$ Simple indigenous architecture helps characterize the enemy, not as a worthy opponent, but as a blatantly inferior one. ${ }^{55}$ Thematic distinctions between the two columns thus help explain distinctions in their depictions of both military and indigenous architecture.

A comparison of the lowest spirals illustrates the difference in the use of and emphasis on architecture on the two monuments (figs. 15-17). The narrative action for both (Scenes I-III) begins with an illustration of the frontier, followed by a river god rising from the water below a peaceful, fortified town; to the right, the Roman army marches through an arch across a pontoon bridge into provincial territory. ${ }^{56}$ Despite the sequences' obvious

53 Pirson 1996, especially 158; see also Hölscher 2000, 97; Beckmann 2003, 206-7.

54 Coulston 1988, 383; Hölscher 2000, 95.

55 Ferris 2009, 153.

56 Coulston 1988, 384; Beckmann 2003, 30; id. 2011, 89-98. The two renderings of these scenes are similar enough that Beckmann $(2003,30 ; 2011,96)$ has suggested that the bottom scenes of the Column of Marcus Aurelius are based on a direct sketch of the bottom scenes of Trajan's. 


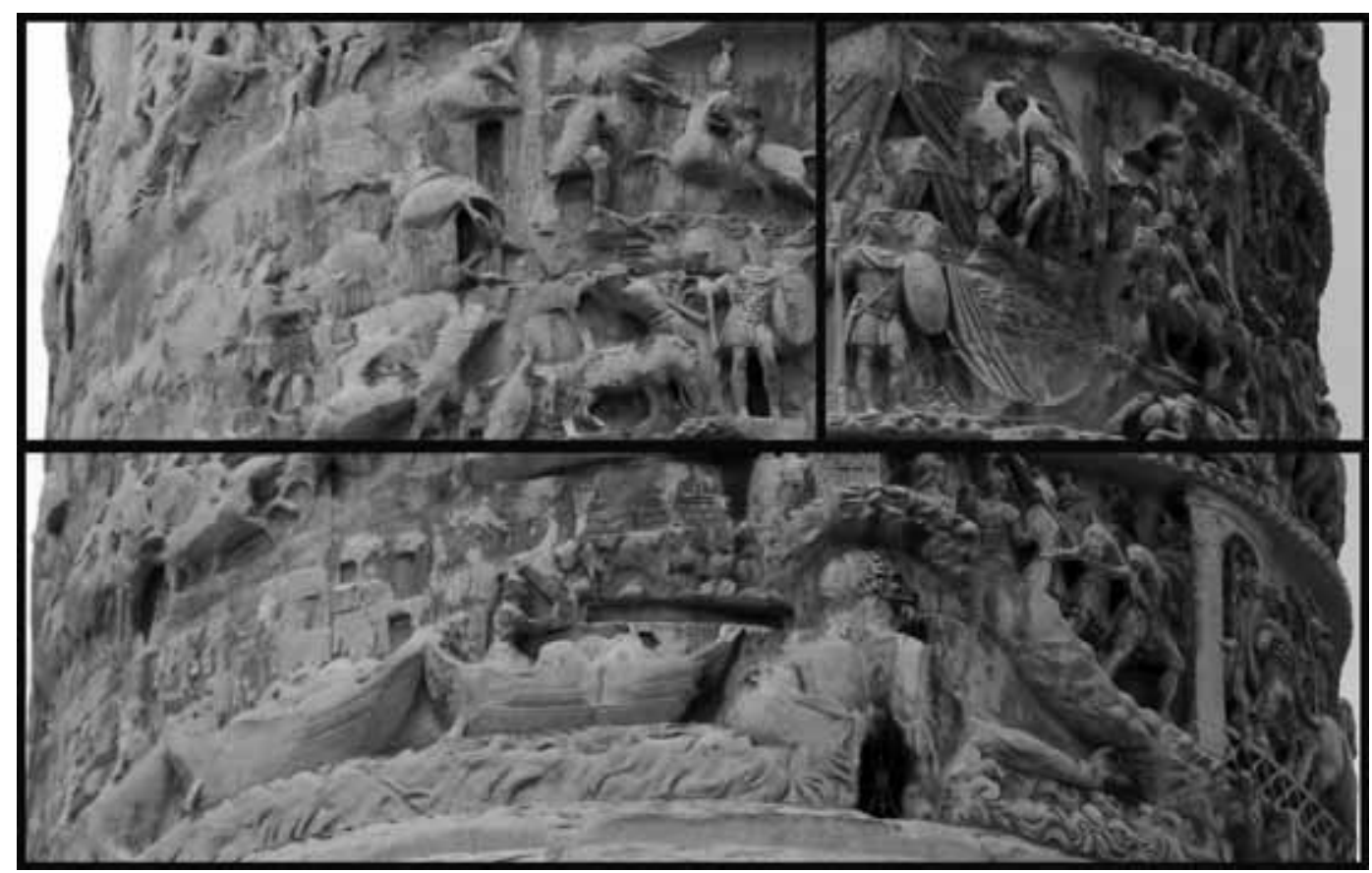

Fig. 17. Column of Marcus Aurelius, use of architecture on two lowest spirals. Upper left: destruction of indigenous architecture; upper right: emperor and group; below: river god and settlement (author).

similarities, the architecture in the two is not identical. Trajan's Column opens with two short stone buildings with wooden palisades, followed by three taller stone buildings with wooden palisades and torches sticking out of windows. The later column opens with 4 short buildings, which, though identical in shape to those beginning Trajan's, differ in construction material from each other and from their models: in particular, the third building from the right (see above) is made of organic material with an organic palisade. ${ }^{57}$ The later column adds a wooden palisade running behind the first buildings all the way to the fortified town, which is greatly reduced in size and detail compared to the example on Trajan's. Finally, on the later column the Roman army marches through a freestanding arch connected to the pontoon bridge; on Trajan's the army marches through the arched gate of the fortified town. The opening sequence of Trajan's Column emphasizes sophisticated, permanent stone architecture provided for a peaceful, friendly frontier, an emphasis not repeated systematically on the later column.

\section{Architectural destruction and cultural obliteration on the Column of Marcus Aurelius}

Like Trajan's, the later column uses architectural destruction to illustrate the extermination of indigenous culture, but the employment of this motif is not identical on both monuments. Of the 12 architectural groupings with indigenous architecture on the later column, seven feature its destruction (figs. $12-14$ and 17-18). ${ }^{58}$ If one adds Scene XLVIII where Roman soldiers torch fields, there are 8 instances where Roman soldiers actively

57 The first building (proceeding left to right) is stone with no palisade, the second is stone with a wooden palisade, the third is of organic material with an organic palisade, and the fourth, heavily damaged, is certainly stone and probably lacked a palisade; see Ferris 2009, 155 (omitting the fourth building), Beckmann 2011, 89-91 for discussion. 


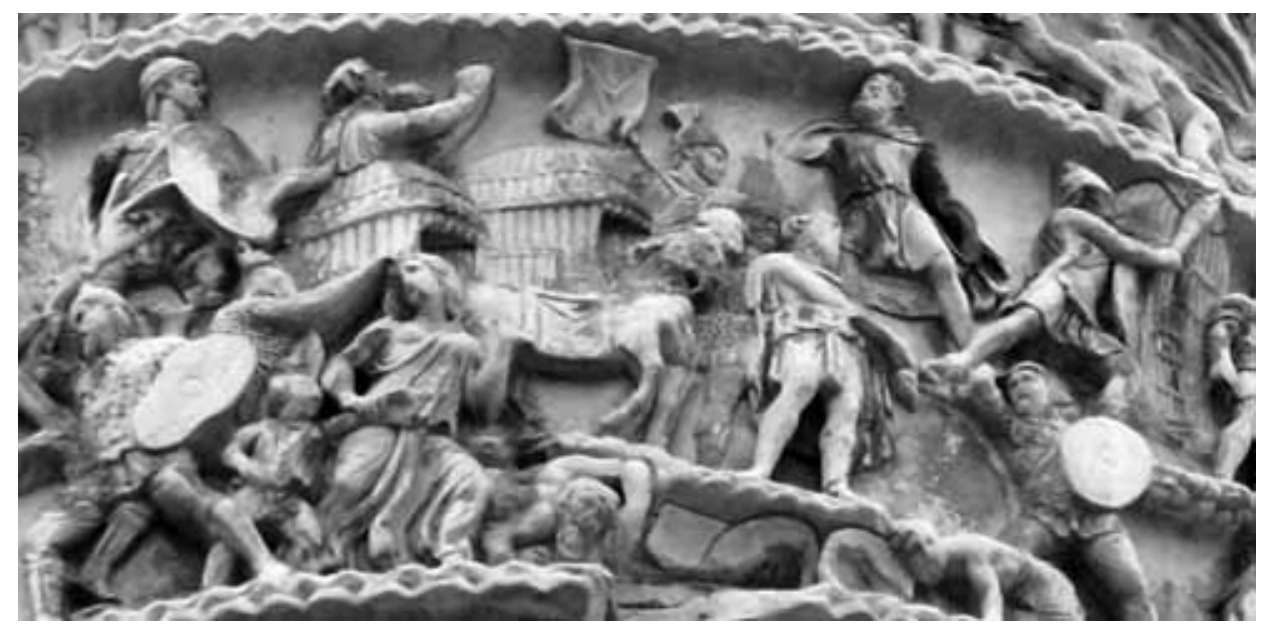

Fig. 18. Column of Marcus Aurelius, destruction of indigenous architecture, interspersed with violence towards barbarian men, women and children (Scene XX; author).

burn or destroy elements of the indigenous landscape. This emphasis on destruction stands in stark contrast to the 3 (at most) depictions of peaceful towns. ${ }^{59}$ These numbers can be compared to Trajan's Column with its 7 unambiguous depictions of destruction but 6 depictions of peaceful towns.

As argued above, architectural destruction on the earlier column often takes on an abstract, symbolic aspect. While the obliteration of Dacian culture is strongly implied, this destruction is separated from the literal destruction of the Dacian people themselves. Although Dacians are often compositionally placed near the destruction of their buildings, precise chronological and spatial relationships are not clear. In the first and third destruction sequences where Dacian men watch the fire, some spatial separation is implied since their background is differentiated from that of the Roman soldiers, with whom they do not interact (figs. 3 and 6 [below]). In the second destruction sequence, the chiastic arrangement demarcates the architectural destruction from the violence against the Dacians themselves (fig. 4). Only in the fifth sequence is destruction directly paired with Roman violence against Dacians, and here there is a wall (albeit crumbling) between the Dacian and Roman soldiers (fig. 8). The fourth sequence is non-violent, and Dacians are not even present in the final destruction sequence. In the sixth, where violence is clearly paired with architectural destruction, it is Dacians who kill Dacians.

By contrast, in two instances on the later column - including Scene XX, the column's most elaborate depiction of architectural destruction - the destruction of architecture is interspersed with the graphic humiliation and execution of barbarians, including women and children (fig. 18). ${ }^{60}$ In three further instances, slaughter and architectural destruction are not completely integrated but scenes of destruction are immediately and seamlessly followed by scenes of violent battle. ${ }^{61}$ The destruction of architecture is not symbolically independent; rather, it works with and within scenes illustrating violence directed against the persons of rebellious barbarians.

59 Scenes II, XL, CXIII; see supra n.41.

60 Scenes XX, CII; Pirson 1996, 142-43 and 166-67; Beckmann 2003, 58.

61 Scenes XLVI, LXXI and XCVIII. 
The later column also presents variations on architectural destruction not found on Trajan's. The most famous example is Scene XI (fig. 14), the 'miracle' of an indigenous siege-tower destroyed by lightning. ${ }^{62}$ This unique scene may be historically based, ${ }^{63}$ but its inclusion and rendering is nonetheless significant. The siege-tower may represent the perverse use of Roman siege technology by barbarians, an idea already present, for example, in Caesar's Bellum Gallicum, ${ }^{64}$ where Vercingetorix says that the Roman victory at Avaricum was achieved not by courage or skill in pitched battle, but 'by stratagem and by knowledge of siege operations, in which the Gauls had had no experience'. ${ }^{65}$ Instead, the Gauls in the Bellum Gallicum rely on siege engineering technology learned illicitly from the Romans (5.43.7; 7.81.1). In keeping with this motif and the general tenor of indigenous architecture on the frieze, the siege-tower on the later column is depicted as a primitive plank structure, unlike the more elaborate Roman siege engines seen, for example, on Trajan's Column (Scene LXXV) or the Arch of Septimius Severus (Panel III ${ }^{66}$ ). The primary connotations of the structure on the later column would be negative, playing into a traditional motif of barbarian incompetence in sieges. ${ }^{67}$ The vivid, violent destruction of this structure would underscore its negative connotations and demonstrate the support of nature in the destruction of indigenous culture.

Some original destruction scenes on the later column, however, do not seem to have specific historical impetus. Scene XCVIII appears to show the destruction of something by Roman soldiers using dolabrae, similar to Scene CXVI on Trajan's Column, but the destruction does not take place in the context of battle. ${ }^{68}$ Scene XLVIII shows Roman soldiers raising torches to indigenous fields. ${ }^{69}$ Unlike the Lightning episode, neither of these scenes would seem to represent historical incidents of great importance; rather, they are creative variations on the theme of destruction of the indigenous landscape. The architectural destruction on the later column does not simply reproduce or imitate the motif on Trajan's Column but modifies and expands upon its precursor in this respect.

The later column also emphasizes architectural destruction to a degree not found on Trajan's. Sixty percent of indigenous architectural assemblages on the later column occur within narratives of destruction. Five instances of destruction occur within the narrative of the First War, towards the bottom of the shaft (fig. 12), and three occur within the first 4 spirals - in other words, before the equivalent position of the first destruction sequence

While the siege-tower may be meant to represent the use of Roman technology by barbarians, several factors argue for treating the siege-engine as indigenous: (a) it is depicted as a crude plank structure; (b) it is operated by barbarians against Romans; (c) it is destroyed violently, which would be unprecedented for the depiction of architecture with primarily Roman connotations.

63 For the problems regarding the possible historicity of this scene, see Beckmann 2011, 133-40.

64 For the general Roman stereotype of barbarians as incapable of conducting sieges, see Rawlings 1988, 174; Roth 2006.

65 Caes., BG 7.29.2: non virtute neque in acie vicisse Romanos, sed artificio quodam et scientia oppugnationis, cuius rei fuerint ipsi imperiti (ed. W. Hering, Teubner edn. 1987; transl. Edwards, Loeb edn., 42); see also 2.12.5, 2.30.3-31.3.

66 I follow here R. Brilliant's (1967, 175-76) system for numbering the panels on the Arch of Septimius Severus in Rome.

67 The only Dacian siege equipment shown on Trajan's Column is a hand-held battering ram (Scene XXXII).

68 See supra n.47.

69 This scene is followed immediately by a scene of violence against barbarians. 
(XXV) on Trajan's Column (fig. 2). Many of the instances, including two in the first 4 spirals, are arranged in important axial positions (fig. 12). Scene XX, where Roman soldiers burning huts frame illustrations of soldiers grabbing women and children and slaying men, appears in a strategic position directly above the Rain Miracle $\left(\mathrm{XVI}^{70}\right)$, which in turn sits above the Roman fortification of the Lightning Miracle (XI), above an arch through which the army marches as it first crosses the Danube (the end of Scene III) (figs. 12 and 18). ${ }^{71}$ This eastern axis, which would have faced the via Flaminia and includes the Victory figure of Scene LV, was the column's most important axis, one central to its layout and design. ${ }^{72}$ Scenes XLVI and XCVIII higher up, also featuring destruction, sit near or on this axis.

Again, a survey of the lowest two spirals of the two columns can highlight differences in their emphasis on architectural destruction (figs. 2, 12 and 16-17). A viewer surveying Trajan's Column from directly below the depiction of the river god would have seen, in the spiral above, Trajan addressing a group of Roman soldiers, followed to the right by an extended depiction of legionaries constructing a stone fort. In the case of the later column, on the other hand, a viewer in the equivalent position below the river god would have seen in the subsequent spiral an extensive depiction of destruction of indigenous architecture, followed by the emperor addressing a group of barbarians. ${ }^{73}$ The emperor's address to a group of his soldiers on the earlier column is replaced by his triumphant reception of barbarians on the later column. Likewise, the construction of new Roman architecture is replaced by the destruction of indigenous architecture. The earlier column's emphasis on the construction of a new permanent civilization in the provinces is exchanged for an emphasis on the violent destruction of the old civilization.

The distinctions in the use of architecture on the two monuments can have implications for broader discussions. There has been debate as to whether or not the many differences in the two monuments' treatment of barbarians reflect actual differences in the wars they commemorate. ${ }^{74}$ In particular, some scholars have argued that the earlier column's more reserved depiction of war can be connected to the Dacian Wars' character as campaigns of conquest and assimilation, whereas the comparatively violent representations on the later column are derived from waging a war of punishment against rebellious, unrepentant barbarians. This view has recently been criticized: for example, in her treatment of representations of women S. Dillon convincingly argues that to suppose that rape and abuse were not part of Trajan's invasion of Dacia just because they are not depicted on the column is to be naïvely optimistic. ${ }^{75}$ Instead, she argues for an ideological, rather than historical, motivation for the varying treatment of women and children on the two monuments.

70 For the narrative of this scene and its historical connections, see Kovács 2009; also Coulston 1988, 382; Wolff 1990, 9; Beckmann 2003, 5-6 and 171-77; id. 2011, 26-28 and 134-40; Clarke 2003, 47; Coarelli 2008, 54-56.

71 Beckmann $(2003,201)$ believes that at least Scene XX, and presumably earlier scenes, could have been clearly seen by the ancient viewer; see also Coulston 1988, 382.

72 Coulston 1988, 384; Beckmann 2003, 27 and 197.

73 For the thematic differences between the opening narratives, see Hölscher 2000, 96.

74 For general discussion, see Coulston 1988, 382; Pirson 1996, 139-41; Dillon 2006a, 244; Beckman 2011, 194-202. For the view that the differing depictions of barbarians reflect actual differences in the nature of the wars themselves, see Coulston 1988, 382-83; Pirson 1996, 171-77; Zanker 2000, 171-73; Beckmann 2003, 208; id 2011, 194-202. 
A similar argument must be made concerning the depictions of architectural destruction. The Roman army was rarely noted for its kindness. Whatever the emperor's eventual goal for a territory, whether incorporation or punishment, the immediate means used to achieve either were probably similar, and undoubtedly violent. ${ }^{76}$ The architectural destruction on Trajan's Column is depicted as relatively restrained, but that does not mean that the burning of a Dacian village at the hands of the invading Roman army was not a terrifying, bloody, and frequent occurrence. Neither column is a war documentary, and the differences in their handling of the destruction of indigenous architecture should be related to distinctions in the monuments' messages rather than to distinctions in how the wars they commemorate were conducted. Showing a controlled destruction of indigenous architecture on Trajan's Column helps to epitomize and emphasize what the monument depicts as the idealized replacement of a rebellious indigenous culture with Rome's peaceful rule. In contrast, the more literal depictions of architectural destruction on the later column add to that monument's broader picture of total war and punishment directed against markedly inferior barbarians. ${ }^{77}$

\section{Conclusion}

The illustration of architectural destruction on the two columns was an integral part of the effect and intended messages. On Trajan's, the peace ensured by Roman rule was set in direct contrast to the temporary nature of a rebellious indigenous culture and to its violent destruction. Depictions of the destruction of indigenous architecture served as a symbolic yet vivid contrast to the more numerous depictions of peaceful towns acclimated to Roman culture and the new architecture constructed by the Roman army. At the same time, the manner in which the destruction is illustrated presented what was essentially an aggressive, brutal action as a controlled, emblematic act of war. This is in keeping with the general tone of this column as a whole where Trajan supervises but does not engage in battle, and where legionaries move in organized formations, constructing fortifications as they go.

Since Dacia was eventually incorporated as a province, it is assumed that this was one of Trajan's original goals in waging war. Nevertheless, scholarship on the history and archaeology of the Dacian Wars has tended to see the wars as particularly violent and demographically devastating (e.g., Ehrhardt 1970, 223; Haynes and Hanson 2004a, 19-20; Oltean 2004, 145; Ruscu 2004). For a cautionary argument against this viewpoint, see Ellis 1998, 229; Lockyear 2004, 50-51.

Marcus Aurelius' eventual goals for the area around the Rhine are unclear. Dio (72.13.1-2) indicates that the emperor was bent on annihilating at least a portion of his enemies (cf. Beckmann 2003, 205), but the Historia Augusta (SHA Marcus 1.5) records that Marcus Aurelius intended to incorporate the area into the empire (Pirson 1996, 174; Beckmann 2011, 4). Mattingly (2011, especially 3-42) has recently argued for a move away from traditional, sanitized views of the Roman Empire as a beneficial and civilizing influence, towards a conception of Roman imperialism as a violent and aggressive force emphasizing power and subservience. He calls attention to the often under-emphasized fact that in the Roman Empire "the façade of civil government was underpinned by violence, both real and latent" (4), and argues that "we are ...too accepting at face value of the assurances of our sources about the good intentions of Rome and its principal imperial actors" (272).

77 For a general ideology of punishment on the Column of Marcus Aurelius, see, e.g., Pirson 1996, 173-76; Hölscher 2000, 95 and 97-105; Beckmann 2003, 202-8; id. 2011, 194-202; Coarelli 2008, 66; Kovács 2009, 158. 
On the Column of Marcus Aurelius, the destruction of indigenous architecture is at once more literal and more prominent than it is on Trajan's. Architectural destruction is not retained as a detached proxy for the dissolution of a culture; instead, it is woven within tableaux of terrible violence directed against men, women, and children. Barbarian culture is destroyed, and with it the barbarians themselves. Examples of architectural (and agricultural) destruction are more frequent and are generally set lower along the column than on Trajan's. Destruction thereby plays an important rôle in establishing the tone and themes of the column's narrative by illustrating and emphasizing the campaign of violence waged by the Roman army against a barbarian enemy it is intent on destroying.

The columns' images of destruction draw upon a long tradition of Roman use of architectural destruction to evoke ideas of conquest and cultural superiority. Depictions of the architecture of captured peoples were an important part of triumphal processions, and in at least one instance this architecture was depicted as subject to destruction. ${ }^{78}$ The description by Josephus of paintings made for the Jewish triumph of Vespasian and Titus records elaborate images of captured temples and houses on fire, ${ }^{79}$ although in this case the inclusion of architectural destruction may be related to the notorious destruction of the Temple in Jerusalem. Destruction was not limited to visual depictions: literary sources such as Caesar's Bellum Gallicum and Livy's Ab urbe condita are replete with examples of the sacking of cities and destruction of villages. Nevertheless, the columns' imagery of destruction has no extant visual parallels, ${ }^{80}$ making their images an important window into a tradition and approach to architecture that in visual terms is largely lost.

The two columns present two different approaches to the illustration of imperial expansion and war, yet the most basic message of the architectural destruction was ultimately similar. The violent destruction of indigenous architecture both illustrated and encapsulated the destruction of resistant indigenous culture in the face of Rome's advance. The Roman army as it is depicted on both monuments was not concerned with modern notions of multicultural acceptance or civilian protection. In the world of the columns, the proper response to Roman imperialism was total acceptance and assimilation, while the proper Roman response to resistance was violent destruction, with architecture serving to exemplify indigenous culture. The images of architectural destruction on the two monuments can help us understand how different régimes approached, conceptualized and depicted conquest, and can shed light on Roman conceptual relationships between architecture and culture. ethill@unc.edu

University of North Carolina, Chapel Hill

78 For discussion of triumphal paintings, see Coulston 1988, 131 and 165; Holliday 1997; Hölscher 2002, 38 and 44; Beckmann 2003, 85-86; Lusnia 2006; Brilliant 2007, 485. For the inclusion of architectural depictions in triumphs and triumphal painting, see Coulston 1988, 165; Hölscher 1991b, 293-94; id. 2006, 37 and 39; Holliday 1997, 129-30 and 134-37; La Rocca 2000, 63; Settis 2005, 75-77; Favro 2006, 25-26; Lusnia 2006, 286. It is not clear how often the architecture included in these paintings would have been shown as subject to destruction. For the influence of triumphal paintings on Trajan's Column, see Lehmann-Hartleben 1926, 2 and 29; Coulston 1988, 124 and 131-32; id. 1990b, 295; Settis 1988, 94-96; Hölscher 1991b, 293-94; Coarelli 2000, 11; Koeppel 2002, 248; Beckmann 2003, 111-13. For the possible influence of triumphal paintings on the Column of Marcus Aurelius, see Beckmann 2003, 164-65.

79 BJ 7.139-48.

80 The Arch of Septimius Severus in Rome implies architectural destruction through its inclusion of Roman siege equipment, but it does not show the actual burning of indigenous buildings. 


\section{Acknowledgements}

This article is derived from my Master's Thesis at the University of North Carolina at Chapel Hill (Wolfram 2007). I am very grateful to Sheila Dillon and Nicola Terrenato for their advice. As always, special thanks are due to my chair Monika Truemper, a tireless source of sound advice and encouragement as well as a fine editor of my work. My thanks extend also to the Institute for Humane Studies, which provided crucial support for several trips to Rome. I am also grateful to Martin Beckmann for allowing me to use his drawing of the Column of Marcus Aurelius as the basis for my fig. 12, and for sharing with me advance drafts of his most recent book. I thank Elizabeth Robinson for kindly taking photographs of the Column of Marcus Aurelius for this article. I am also grateful to the editor of $J R A$ and the anonymous reviewers for their valuable comments; all remaining mistakes are my own. This article was originally presented in part at the 111th Annual Meeting of the Archaeological Institute of America held at Anaheim, CA, in January 2010.

\section{Bibliography}

Antonescu, D. 2009. Columna lui Traian: Arhitectura de pe friza sculptată (Bucharest).

Baumer, L. E., T. Hölscher, and L. Winkler 1991. "Narrative Systematik und Politisches Konzept in den Reliefs der Traianssäule. Drei Fallstudien," JdI 106, 261-95.

Beckmann, M. 2003. The battle scenes on the Column of Marcus Aurelius (Ph.D. diss., McMaster Univ., Hamilton).

Beckmann, M. 2005. "The border of the frieze of the Column of Marcus Aurelius and its implications," JRA 18, 302-12.

Beckmann, M. 2006. “The direction of carving on the Columns of Trajan and Marcus Aurelius," Röm Mitt 112, 225-36.

Beckmann, M. 2011. The Column of Marcus Aurelius. The genesis $\mathcal{E}$ meaning of a Roman imperial monument (Chapel Hill, NC).

Behn, F. 1919a. "Die Markomannenhütten auf der Markussäule," Germania 3, 52-55.

Behn, F. 1919b. “Nochmals die Markomannenhütten auf der Markussäule," Germania 3, 83-84.

Brilliant, R. 1967. The Arch of Septimius Severus in the Roman Forum (MAAR 29).

Brilliant, R. 2007. "With violence and for profit: Romans at war," JRA 20, 481-86 [review of Dillon and Welch 2006].

Caprino, C. et al. (edd.) 1955. La Colonna di Marco Aurelio (Rome).

Cichorius, C. 1896-1900. Die Reliefs der Traianssaule (Berlin).

Claridge, A. 1993. “Hadrian's Column of Trajan," JRA 6, 5-22.

Claridge, A. 2005. "Further considerations on the carving of the frieze on the Column of Marcus Aurelius," JRA 18, 313-16.

Claridge, A. 2007a. “Back to Trajan's Column of Trajan," JRA 20, 467-68 [review of Coarelli 2000].

Claridge, A. 2007b. "Hadrian's lost temple of Trajan," JRA 20, 54-94.

Clarke, J. 2003. Art in the lives of ordinary Romans (Berkeley, CA).

Coarelli, F. 2000. The Column of Trajan (Rome).

Coarelli, F. 2008. La Colonna di Marco Aurelio (Rome).

Coulston, J. C. N. 1988. Trajan's Column: the sculpting and relief content of a Roman propaganda monument (Ph.D. diss., Univ. of Newcastle-on-Tyne).

Coulston, J. C. N. 1990a. “The architecture and construction scenes on Trajan's Column," in M. Henig (ed.), Architecture and architectural sculpture in the Roman Empire (OUCA Monog. 29) 39-50.

Coulston, J. C. N. 1990b. “Three new books on Trajan's Column,” JRA 3, 290-309 [review of La Colonna Traiana e gli artisti francesi da Luigi XIV a Napoleone I; Lepper and Frere 1988; and Settis 1988]

Davies, G. A. T. 1920. "Topography and the Trajan Column," JRS 10, 1-28.

Depeyrot, G. 2007. Optimo principi: iconographie, monnaie et propagande sous Trajan (Coll. Moneta 68-70; Wetteren).

Diaconescu, A. 2004. "The towns of Roman Dacia: an overview of recent research," in Haynes and Hanson 2004, 87-142.

Dillon, S. and K. Welch (edd.) 2006. Representations of war in ancient Rome (Cambridge).

Dillon, S. 2006a. "Women on the Columns of Trajan and Marcus Aurelius and the visual language of Roman victory," in Dillon and Welch 2006, 244-71.

Drexel, F. 1918. “Die germanischen Hütten auf der Markussäule," Germania 2, 114-18.

Ehrhardt, C. 1970. “What should one do about Dacia?" Class. World 63.7, 222-26. 
Ellis, L. 1998. “'Terra deserta': population, politics, and the [de]colonization of Dacia," World Arch. 30.2, 220-37.

Elsner, J. 2000. "Frontality in the Column of Marcus Aurelius," in Huet and Scheid 2000, 251-64.

Favro, D. 2006. “The iconiCITY of ancient Rome," Urban History 33.1, 20-38.

Ferris, I. M. 2009. Hate and war: the Column of Marcus Aurelius in Rome (Stroud).

Galinier, M. 2007. La colonne trajane et les forums impériaux (CollEFR 382).

Gros, P. 2005. "Les enjeux historiques du débat sur l'ordonnance du Forum de Trajan," CRAI, 173-97.

Grunow, M. D. 2002. Architectural images in Roman state reliefs, coins, and medallions (Ph.D. diss., Univ. of Michigan, Ann Arbor).

Hanoune, R. 2000. "Représentations de construction et d'architecture sur la colonne aurélienne," in Huet and Scheid 2000, 205-11.

Hanson, W. S. 1982. "Roman military timber buildings: construction and reconstruction," in S. McGrail (ed.), Woodworking techniques before A.D. 1500 (BAR S129; Oxford) 169-86.

Haynes, I. P. and W. S. Hanson (edd.) 2004. Roman Dacia: the making of a provincial society (JRA Suppl. 56).

Haynes, I. P. and W. S. Hanson 2004a. "An introduction to Roman Dacia," in Haynes and Hanson 2004, 11-31.

Hobley, B. 1982. "Roman military structures at 'The Lunt' Roman fort: experimental simulations," in P. J. Drury (ed.), Structural reconstruction: approaches to the interpretation of the excavated remains of buildings (BAR S110; Oxford) 223-74.

Holliday, P. 1997. "Roman triumphal painting: its function, development, and reception," ArtB 79, 130-47.

Hölscher, T. 1991a. "Einleitung," in Baumer, Hölscher and Winkler 1991, 261-66.

Hölscher, T. 1991b. "Vormarsch und Schlacht," in Baumer, Hölscher and Winkler 1991, 287-95.

Hölscher, T. 1999. "Alle Welt für Traian. Beobachtungen zur Darstellung von Fremdvölkern an traianischen Staatsdenkmälern," in N. Blanc and A. Buisson (edd.), Imago antiquitatis. Religions et iconographie du monde romain. Mélanges offerts à Robert Turcan (Paris) 281-89.

Hölscher, T. 2000. "Die Säule des Marcus Aurelius: narrative Struktur und ideologische Botschaft," in Huet and Scheid 2000, 89-105.

Hölscher, T. 2002. "Bilder der Macht und Herrschaft," in A. Nünnerich-Asmus (ed.), Traian. Ein Kaiser der Superlative am Beginn einer Umbruchzeit (Mainz) 127-44.

Hölscher, T. 2006. "The transformation of victory into power: from event to structure," in Dillon and Welch 2006, 27-48.

Huet, V. and J. Scheid (edd.) 2000. La colonne aurélienne. Autour de la colonne aurélienne. Geste et image sur la colonne de Marc Aurèle à Rome (Turnhout).

Johnson, A. 1983. Roman forts of the 1st and 2 nd centuries AD in Britain and the German provinces (New York).

Jordan-Ruwe, M. 1990. “Zur Rekonstruktion und Datierung der Marcussäule," Boreas 13, 53-69.

Koeppel, G. 1991. “Die historischen Reliefs der römischen Kaiserzeit VIII: Der Fries der Trajanssäule in Rom. Teil 1," BJb 191, 135-98.

Koeppel, G. 1992. “Die historischen Reliefs der römischen Kaiserzeit VIII: Der Fries der Trajanssäule in Rom. Teil 2," BJb 192, 61-122.

Koeppel, G. 2002. "The Column of Trajan. Narrative technique and the image of the emperor," in P. A. Stadter and L. Van der Stockt (edd.), Sage and emperor. Plutarch, Greek intellectuals, and Roman power in the time of Trajan, 98-117 A.D (Leuven) 245-57.

Kovács, P. 2009. Marcus Aurelius' rain miracle and the Marcomannic Wars (Mnemosyne Suppl. 308).

La Rocca, E. 1994. "Ferocia barbarica. La rappresentazione dei vinti tra Media Oriente e Roma," JdI $109,1-40$.

La Rocca, E. 2000. “L'affresco con veduta di città dal colle Oppio," in E. Fentress (ed.), Romanization and the city (JRA Suppl. 38) 57-71.

La Rocca, E. 2004. “Templum Traiani et Columna Cochlis," RA 111, 193-238.

Lancaster, L. 1999. "Building Trajan's Column," AJA 103, 419-39.

Lehmann-Hartleben, K. 1926. Die Trajanssäule: Ein römisches Kunstwerk zu Beginn der Spätantike (Berlin).

Lepper, F. and S. Frere 1988. Trajan's Column: a new edition of the Cichorius plates (Wolfboro, NH).

Lockyear, K. 2004. "The Late Iron Age background to Roman Dacia," in Haynes and Hanson 2004, 33-74.

Lusnia, S. S. 2006. "Battle imagery and politics on the Severan Arch on the Roman Forum," in Dillon and Welch 2006, 272-99. 
Mattingly, D. J. 2011. Imperialism, power, and identity: experiencing the Roman Empire (Princeton, NJ).

Meneghini, R. 2001. “La nuova immagine architettonica del Foro di Traiano," in F. Farina (ed.), Tra Damasco e Roma: l'architettura di Apollodoro nella cultura classica (Rome) 48-65.

Meneghini, R. 2007. "I fori imperiali nell'antichità: il Foro di Traiano," in id. and R. Santangeli Valenzani (edd.), I fori imperiali: gli scavi del Comune di Roma (1991-2007) (Rome) 83-113.

Meneghini, R. 2009. I fori imperiali e i mercati di Traiano. Storia e descrizione dei monumenti alla luce degli studi e degli scavi recenti (Rome).

Mielke, R. 1915. “Die angeblich germanischen Rundbauten an der Markussäule in Rom," Z.f. Ethnologie 47, 75-91.

Oltean, I. A. 2004. “Rural settlement in Roman Dacia: some considerations," in Haynes and Hanson 2004, 143-64.

Packer, J. 1997. The Forum of Trajan in Rome: a study of the monuments (California Studies in the History of Art 31; Berkeley, CA).

Packer, J. 2003. "Templum Divi Traiani Parthici et Plotinae: a debate with R. Meneghini," JRA 16, 108-36.

Packer, J. 2008. "The Column of Trajan: the topographical and cultural contexts," JRA 21, 471-78 [review of Galinier 2007].

Petersen, E. A. H., A. v. Domaszewski and G. Calderini (edd.) 1896. Die Marcus-Säule auf der Piazza Colonna (Munich).

Pirson, F. 1996. "Style and message on the Column of Marcus Aurelius," PBSR 64, 139-79.

Rawlings, L. 1998. "Caesar's portrayal of Gauls as warriors," in K. Welch and A. Powell (edd.), Julius Caesar as artful reporter: the War Commentaries as political instruments (London) 171-92.

Richmond, I. 1982. Trajan's army on Trajan's Column (London).

Rockwell, P. 1985. "Preliminary study of the carving techniques on the Column of Trajan," in P. Pensabene (ed.), Marmi antichi: problemi d'impiego, di restauro e d'identificazione (StMisc 26) 101-11.

Rossi, L. 1968. “The representation on Trajan's Column of Trajan's rock-cut road in Upper Moesia: the emperor's road to glory," AntJ 48, 41-46.

Rossi, L. 1971. “Dacian fortifications on Trajan's Column,” AntJ 51, 30-35.

Roth, J. 2006. "Siege narrative in Livy: representation and reality," in Dillon and Welch 2006, 49-67.

Ruscu, D. 2004. "The supposed extermination of the Dacians: the literary tradition," in Haynes and Hanson 2004, 75-85.

Settis, S. 1988. "La colonna: strategie di composizione, strategie di lettura," in id. (ed.), La colonna traiana (Turin) 116-255.

Settis, S. 2005. “La colonna traiana: l'imperatore e il suo publico," in F. Bertini (ed.), Giornate filologiche "Francesco Della Corte" IV (Genova) 65-86.

Stefan, A. S. 2005. Les guerres daciques de Domitien et de Trajan: architecture militaire, topographie, images et histoire (CollEFR 353).

Turcan-Déléani, M. 1956. “Les monuments représentes sur la colonne trajane: schématisme et réalisme," MEFRA 70, 149-76.

Winkler, L. 1991. “Die Opferszenen der Trajanssäule. Bedeutung innerhalb der Narrativen Systematik," in Baumer, Hölscher and Winkler 1991, 267-77.

Wolff, H. 1990. “Welchen Zeitraum stellt der Bilderfries der Marcus-Säule dar?,” Ostbairische Grenzmarken (Passauer Jb f. Geschichte 32) 9-29.

Wolfram, E. 2007. The glory of Rome: depictions of architecture on the Column of Trajan (M.A. thesis, Univ. of North Carolina, Chapel Hill).

Wolfram Thill, E. 2010. "Civilization under construction: depictions of architecture on the Column of Trajan," AJA 114, 27-43.

Zanker, P. 2000. "Die Frauen und Kinder der Barbaren auf der Markussäule," in Huet and Scheid 2000, 163-74. 